\title{
In vitro membrane binding and protein binding (IAM MB/PB technology) to estimate in vivo distribution: applications in early drug discovery
}

\author{
Klara Valko* ${ }^{1}$, Simon Teague ${ }^{2}$, and Charles Pidgeon ${ }^{3}$ \\ ${ }^{1}$ Bio-Mimetic Chromatography, Unit 5B Business \& Technology Centre, Stevenage, SG1 2DX Hertfordshire United \\ Kingdom \\ ${ }^{2}$ GlaxoSmithKline, Stevenage, United Kingdom \\ ${ }^{3}$ Independent Researcher, affiliate of Regis Technologies Inc, Morton Grove, IL 60052 USA
}

*Corresponding Author: E-mail: Klara_Valko@bio-mimetic-chromatography.com; Tel.: +44-7521989558;

\begin{abstract}
The drug discovery process can be accelerated by chromatographic profiling of the analogs to model in vivo distribution and the major non-specific binding. A balanced potency and chromatographically determined membrane and protein binding (IAM MB/PB) data enable selecting drug discovery compounds for further analysis that have the highest probability to show the desired in vivo distribution behavior for efficacy and reduced chance for toxicity. Although the basic principles of the technology have already appeared in numerous publications, the lack of standardized procedures limited its widespread applications especially in academia and small drug discovery biotech companies. In this paper, the standardized procedures are described that has been trademarked as Regis IAM MB/PB Technology ${ }^{\oplus}$. Comparison between the Drug Efficiency Index (DEI=pIC50-logVdu+2) and generally used Ligand Lipophilicity Efficiency (LLE) has been made, demonstrating the advantage of measured IAM and HSA binding over calculated log P. The power of the proposed chromatographic technology is demonstrated using the data of marketed drugs.
\end{abstract}

\section{Keywords}

Drug efficiency; Biomimetic properties by HPLC; unbound volume of distribution; in vivo distribution

\section{Introduction}

Medicinal chemists face multi-factorial challenge problems when designing drug molecules that can reduce the impact or cure a pathological condition; drug discovery scientists seek the smallest possible dose with minimal side effects [1-4]. Screening cascades often generate vast quantities of primarily in-vitro data, and in some cases, in vivo data on compounds that form a decision on which compounds are selected for further progression. This paper documents an alternative screening triage which can help to avoid the problem of analysing too much discovery data when choosing lead compounds to pursue.

Chemical structure design of discovery molecules usually focuses on elucidating the structure - activity relationships after identifying the target enzyme/receptor followed by the development of a potency screening method. The active molecules are then tested for a variety of assays for affinity and 
developability, such as enzyme assays, selectivity assays, cellular assays, $\mathrm{CaCo} 2$ or MDCK cell permeability, solubility [5], lipophilicity, microsomal stability, Hep G cell hepatotoxicity, cellular toxicity, [6] etc. All future reference to receptors will have dual meaning referring to either receptor or enzyme targets, for simplicity.

Project teams usually design screening cascades to guide the filtering process of compounds after each measurement, to ensure those compounds that do not meet pre-defined criteria in a particular assay are eliminated from further screening. This sequential screening process frequently excludes compounds with good in vivo drug properties; marketed drugs have appropriate in vivo properties for the disease they are being developed to treat, along with sufficient potency to engage the target and produce the desired effect. The discovery challenge is to recognise that discovery compounds may exhibit high potency, but they may lack acceptable in vivo distribution enabling the compound to achieve a therapeutic free drug concentration at the target receptor in the target tissue(s) in vivo. In vivo properties, particularly distribution, are as important as high potency or receptor occupancy. Regardless of this fact, none of the properties which are typically measured during compound screening is on their own sufficient to predict the compound's fate in vivo or in human clinical trials. This must ultimately be measured. Several other properties should also be measured, which include target binding, selectivity, absorption, distribution, metabolism and elimination (ADME), pharmacokinetics and pharmacodynamics (PK/PD) profile, and of course the safety profile.

In order to find good absorption and bioavailability, chemists have to design molecules which will have good solubility and permeability, and in general lipophilicity. Designing a drug candidate which has good clinical ADME properties, is often much different than designing discovery compounds with simply high receptor binding or potency. Various ligand efficiency parameters have been introduced and frequently used by medicinal chemists that relate the measured potency to some calculated properties of the compounds such as, size and lipophilicity as it has been recently reviewed [7-8]. This manuscript describes how chromatographic analysis can efficiently predict or help select which compounds have the greater probability of becoming lead molecules by balancing the receptor binding or potency with optimum compound distribution in vivo.

Obviously, achieving good oral absorption alone is not sufficient when choosing a drug candidate. Overcoming the body's natural defense mechanisms is also necessary to achieve relevant oral bioavailability as nature has evolved animal and human protection against potentially harmful xenobiotics. Some of these defense mechanisms we need to consider when developing NCE's are: (i) gut metabolism, (ii) efflux processes and (iii) first pass metabolism. Thus, ensuring that discovery molecules are not subject to active efflux and quick elimination or metabolism is current mainstream thinking in most drug discovery processes.

The latest studies show that the most significant problem with the late-stage attrition of discovery molecules is related to safety and efficacy. Many safety-related issues have been directly attributed to the lipophilicity of compounds [9-12] especially when it is measured using Immobilized Artificial Membranes (IAMs). High IAM binding is indicative of the compound's binding to multiple targets or receptors, this is often referred to as compound promiscuity. This may cause unwanted pharmacology or toxicity. It has previously been shown that compounds that require lower clinical dose (ranging between 1-100 mg) and therefore lower efficacious plasma concentrations are less likely to cause toxicity $[9,13]$.

The root cause of these problems is partially dominated by the compounds binding or partitioning into tissue which is predominantly comprised of membrane phospholipids; when this happens, the drug is sequestered into non-specific phospholipid binding sites and is then less available as a free drug near the 
target of interest. Plasma proteins can also reduce the amount of free drug available to interact with enzymes/receptors (and when this happens an increased dose is essential). Thus, the non-specific binding/partitioning of compounds to phospholipids and proteins reduce the available free concentration at the site of action. Thus, increased doses are needed for activity, but, this increases the possibility of undesired pharmacology or toxicity.

This paper focuses on the role of distribution in the Absorption, Distribution, Metabolism and Elimination (ADME) process, without neglecting the absorption and clearance that regulate the magnitude and the frequency of dosing. We propose to design and triage NCEs based on their in vitro distribution behavior that determines the amount/concentration of compounds in various tissue compartments, and the free unbound compartments that are responsible for safety issues and efficacy, respectively. This can be achieved by using some of the major protein components which make up tissues in the body as chromatographic stationary phases, this is called biomimetic chromatography and has been recently reviewed [14].

We also propose that the unbound volume of distribution of compounds is an important parameter to consider, as this in vivo parameter describes the proportion of the dose relative to the free plasma concentration of compounds in steady state [15]. Based on the free drug hypothesis, [16] the free plasma concentration is the same as the free tissue concentration, when no permeability barrier or active transport distorts the thermodynamic equilibrium, between plasma and tissues which contain the therapeutic targets. Though active transporters may have a significant effect on the free concentration of a drug on the two sides of the membrane [17], the concentration difference can be explained by strong binding of the drug to intracellular components. The free concentration difference is usually not more than an order of magnitude on the two sides of the membrane due to active transporters that require constant energy supply to keep the concentration difference. Distorting the thermodynamic equilibrium by two to three orders of magnitude would require constant energy supply (ATP), and the active transporters may become easily saturated.

The unbound volume of distribution can be considered as a proportional parameter to the drug partition coefficient between the free and bound compartments. In this respect, it is very similar to the recently introduced drug efficiency parameter that relates the free bio-phase concentration to the dose. The drug efficiency concept that was introduced by Braggio [18] highlights the importance of the free concentration of the drug in the biophase near the target relative to the dose to achieve efficient PK/PD of a drug molecule. The drug efficiency index, DEl highlights the importance of balancing the potency and drug efficiency of the molecules and is proposed as an alternative parameter to simply focusing on potency, as other ligand efficiency parameters tend to be biased towards [19]. The DEI concept also helps designing drug molecules with a low therapeutic dose that in turn reduce general toxicity.

Table 1 shows the abbreviations and their meaning of the properties that are investigated in this paper, while Table 2 shows the equations how they are calculated and how they are related to each other.

The drug distribution properties are most often characterised by lipophilicity. Lipophilicity has been recognised for a long time as the principal parameter that influences solubility [20,21], permeability [22], tissue binding, protein binding [23,24], toxicity [10], promiscuity [1], clearance [25] etc. Several ligand efficiency parameters contain the lipophilicity and propose to consider the potency relative to the lipophilicity of the compounds, such as Ligand Lipophilicity Efficiency, $\operatorname{LLE}[7,26]$. Recently, the chromatographic lipophilicity has been combined with the number of aromatic rings in the molecules to derive the Property Forecast Index (PFI) [27]. It has been suggested that having a PFI value less than 6 for 
drug discovery compounds increases the probability of improving drug attrition rates.

Table 1. Variables, abbreviations used throughout the text

\begin{tabular}{|c|c|}
\hline IAM & Immobilized Artificial Membrane (HPLC stationary phase_ \\
\hline HSA & Human Serum Albumin \\
\hline AGP & Alpha-1-acid-glycoprotein \\
\hline PPB & Total plasma protein binding \\
\hline $\mathrm{MB}$ & Membrane Binding (measured by IAM) \\
\hline $\mathrm{MB} / \mathrm{PB}$ & Membrane binding and protein binding \\
\hline$V_{\mathrm{dss}}$ & Steady state volume of distribution (dose/plasma concentration) \\
\hline$V_{\mathrm{du}}$ & Steady state unbound volume of distribution (dose/free plasma concentration $=V_{\mathrm{d}} / f_{\mathrm{u}}$ ) \\
\hline$f_{\mathrm{u}}$ & Unbound fraction in plasma \\
\hline DE & Drug efficiency (100* free biophase conc/dose) \\
\hline $\mathrm{DE}_{\max }$ & Drug efficiency measured by MB/PB by HPLC ( $100 *$ free plasma conc/dose) \\
\hline DEI & Drug efficiency index, potency plus log $\mathrm{DE}_{\max }(\mathrm{plc50}+\log \mathrm{DE})$ \\
\hline IAM MB & Membrane binding index, previously known as $\mathrm{CHI}(\mathrm{IAM})$ \\
\hline $\operatorname{clog} \mathrm{P}$ & Calculated logarithm of octanol/water partition coefficient \\
\hline $\log D / P$ & Logarithm of distribution/partition coefficient \\
\hline
\end{tabular}

Table 2. Equations used to predict distribution properties

\begin{tabular}{|l|l|}
\hline $\log K($ IAM $) ;$ Eq. (1) & $=0.29 * \mathrm{e}^{(0.026 \mathrm{MB}+0.42)}+0.7$ \\
\hline $\log K(\mathrm{HSA}) ;$ Eq. (2) & $=\mathrm{e}^{\log k(\mathrm{HSA})}$ \\
\hline $\log K(\mathrm{HSA})$ & $=\log (\% \mathrm{HSAbound} /(101-\% \mathrm{HSA}$ bound $))$ \\
\hline Estimated $\log V_{\text {dss }} ;$ Eq. (3) & $=0.44 * \log \mathrm{K}(\mathrm{IAM})-0.22 * \log \mathrm{K}(\mathrm{HSA})-0.62$ \\
\hline Estimated log $V_{\text {du }} ;$ Eq. (4) & $=0.23 * \log \mathrm{K}(\mathrm{HSA})+0.43 * \log \mathrm{K}(\mathrm{IAM})-0.72$ \\
\hline $\mathrm{DE}_{\mathrm{max}} ;$ Eq. (7) & $=100 / V_{\text {du }}$ \\
\hline LLE & Ligand lipophilicity efficiency $(\mathrm{pIC} 50-\operatorname{clog} P)$ \\
\hline $\log k$ (PPB) (8) & $0.87 * \log k(H S A)+0.17 * \log k(A G P)+0.06 * c M R-0.27$ \\
\hline
\end{tabular}

Lipophilicity has been historically characterised by the octanol/water partition coefficient, $\log P$, for the neutral form of the molecules and by the distribution coefficient, $\log D$, measured at different $\mathrm{pHs}$, mainly at $\mathrm{pH}$ 7.4. $\log P$ is widely used since the work of Hansch [28] who suggested $\log P$ to describe the so-called "random" walk of the drug molecule that reduces its free concentration near the receptor. Lipophilic compounds energetically do not favour residing in the aqueous environment and have a preference to "stick" to any hydrophobic surface in the body. The octanol/water system is able to partially mimic the polar groups with hydrogen bond donor and acceptor properties that may be present in the lipophilic environment in the body and therefore serve as a good model to describe biological distribution. However, the octanol/water lipophilicity and any other lipophilicity measure that does not include cellular membranes and proteins, fails to explain the biological distribution of molecules when they have charge or special shape. An example is the comparison of nifedipine and amlodipine (see Figure 1). Nifedipine is more lipophilic at physiological pH but still, the volume of distribution of amlodipine is 30 times higher, indicating 30 times higher partitioning to tissues then nifedipine. The clearance of nifedipine is $9.8 \mathrm{~mL} / \mathrm{min} / \mathrm{kg}$ [29], and clearance of amlodipine is in a similar range, $7 \mathrm{~mL} / \mathrm{min} / \mathrm{kg}$ [30]. The major difference between the two 
molecules is a basic amine group on amlodipine. The basic group results in amlodipine having a stronger binding to phospholipids than albumin, and this results in a large difference in their volumes of distribution.<smiles>COC(=O)C1=C(C)NC(C)=C(C(=O)OC)C1c1ccccc1[N+](=O)[O-]</smiles>

Nifedipine

$$
\begin{aligned}
& \mathrm{Vd}=0.7 \mathrm{~L} / \mathrm{kg} \\
& \mathrm{HSA} \%=88.8 \\
& \mathrm{MB} \mathrm{IAM}=30.4 \\
& \log \mathrm{D} / \mathrm{P}=3.58 \\
& \mathrm{Cl}=9.8 \mathrm{ml} / \mathrm{min} / \mathrm{kg}
\end{aligned}
$$<smiles>CCOC(=O)C1=C(COCCN)NC(C)=C(C(=O)OC)C1c1ccccc1Cl</smiles>

\section{Amlodipine}

$$
\begin{aligned}
& \mathrm{Vd}=21 \mathrm{~L} / \mathrm{kg} \\
& \mathrm{HSA} \%=91.4 \\
& \mathrm{MB} \mid \mathrm{AM}=51 \\
& \log \mathrm{D}=1.5 \log \mathrm{P}=3.01 \\
& \mathrm{Cl}=7 \mathrm{ml} / \mathrm{min} / \mathrm{kg}
\end{aligned}
$$

Figure 1. Physico-chemical and biomimetic properties of nifedipine and amlodipine

Besides measuring the octanol/water partition coefficients we propose a method of measuring the protein and phospholipid binding of the compounds using reverse phase high-performance liquid chromatography in conjunction with the Membrane Binding/Protein Binding Technology (MB/PB Technology $\left.{ }^{\circledR}\right)$ registered to Regis Technologies inc. Using this approach, we can measure compounds interaction with phosphatidylcholine membrane (IAM), human serum albumin (HSA) and alpha-1-acid glycoprotein (AGP). These are commercially available HPLC stationary phases that contain or mimic these constituents of the body. These include (i) IAMs, (ii) chiral HSA and (iii) chrial AGP.

The IAM concept was introduced by Pidgeon et al. [31-33] and it was the first attempt to emulate the biological membrane on a solid surface. HPLC columns with IAM stationary phase where the phosphatidylcholine moiety is chemically bonded to a solid surface mimic the density of phosphatidylcholine in the biological membrane bi-layer. Other approaches do exist for measuring membrane binding such as using liposome partition measurements or micellar electrophoresis [35-36]. However, they have their limitations and are also very time-consuming. Biomimetic stationary phases have been validated by comparing the retention times obtained on the commercially available ChiralPak-HSA [37-39] and ChiralPak-AGP [40-41] stationary phases result in binding values that are proportional to the albumin and AGP binding of compounds obtained by equilibrium dialysis. When using biomimetic stationary phases the retention time of the compounds is directly proportional to the dynamic equilibrium constant between the mobile phase (buffer at physiological $\mathrm{pH}$ ) and the actual body component (membrane and proteins) in the stationary phase. The process is very similar to the biological distribution processes that are also dynamic (never in real equilibrium unless at steady state) and occurs on the surfaces of the biomimetic stationary phases. The measured membrane binding parameters reflect the threedimensional nature of the molecule's interaction within an in vivo system (the drug, membrane and protein 
stationary phase) that has been demonstrated in the literature [14]. The chromatographic technique to measure these biomimetic properties has several other technical advantages. It can be easily automated; there is no need for concentration determination and measurements. The important thing is, however, to standardise the retention times and binding data by measuring a calibration set of compounds with each compound set to be able to get normalised retention times for each of the stationary phases being used to generate binding data (IAM, HSA and AGP). A detailed description of the standardised methodology for each of the IAM MB/PB stationary phases has recently been published [14].

There are several publications establishing the usefulness of the IAM MB/PB technology to model in vivo drug distribution, such as the volume of distribution model [42], unbound volume of distribution model [43-44] and how they can be used to screen compounds in early drug discovery [45]. It was found that strong IAM MB (CHI IAM > 50) can be related to phospholipidosis [46-47], as well as high volume of distribution and tissue partitioning [43]. Recently, it was found that promiscuity (i.e., a discovery compound binding to multiple receptors) showed good correlation to the IAM MB of drug discovery compounds. The IAM MB data showed a good correlation with the intracellular concentration of compounds, indicating that membrane binding is important to get compounds into the cell [48]. Estimating the potential clinical dose as early as possible is an important aspect of the drug discovery process to help select the optimal compound profile and highest probability of successful progression to the clinic [49-50]. Valko et al. [51] highlighted that the maximum achievable drug efficiency ( $D E_{\max }$ ) that can be obtained assuming (i) $100 \%$ bioavailability, (ii) no permeability barrier and (iii) no active transport could be calculated using in vitro biomimetic measurements, essentially the Regis IAM MB/PB Technology ${ }^{\circledR}$ that we are proposing in this paper as a useful tool in early drug discovery [51]. The drug efficiency concept as a design parameter has the advantage that it can be estimated from in vitro measurements, and can be monitored during the drug development process to see how the early estimation performs when in vivo measurements become available pre-clinically, or from human clinical trials. In this paper, the intention is to show the models and the applicability of the Regis IAM MB/PB Technology ${ }^{\circledR}$ in early drug discovery. It is also important to have the ability to estimate these in vitro properties from the chemical structure thus helping the design stage of the molecules too. It has been shown that the retention of compounds obtained on the proposed biomimetic stationary phases can be estimated in silico [52-55], however it is worth noting that the in silico models use 2D molecular descriptors that are not sufficient to estimate the $3 \mathrm{D}$ contribution of the molecules binding to proteins, therefore they can be used only as a rough estimations.

Phospholipids constitute approximately $40 \%$ of the human body, therefore, the phospholipid binding of compounds are a very important parameter that should not be ignored in the drug design process. It was found that MB IAM values above 50 indicate promiscuous binding [57], and higher phospholipidotic potential [56-59] for discovery compound. It was also found that MB IAM showed a good correlation with the total cellular concentration of discovery compounds [60].

In this paper, we present the models for human clinical unbound volume of distribution and drug efficiency using measured biomimetic properties, and we describe a protocol how to use these data in early lead optimisation.

\section{Experimental}

The values for dose, potency (pIC50), the volume of distribution, clearance, the half-life of the known drugs were obtained from various databases (www.drugbank.ca/drugs and www.drugs.com) and listed in Table A1. The measured IAM MB/PB data are published in the book by Valko [45] and listed in Table A2. Table $\mathrm{A} 2$ contains the estimated volume of distribution (IAM MB/PB $\log V_{\text {dss }}$ ) and the estimated unbound 
volume of distribution (IAM MB/PB $\log V_{\text {du }}$ ) using the published models [42-43], and the Regis IAM MB/PB Technology ${ }^{\circledast}$. The same technology has been applied to estimate the Maximum Drug Efficiency (HPLC DEmax) value, that represents the maximum drug efficiency that can be achieved when the bioavailability is $100 \%$, and there is no permeability barrier or active transport to disturb the steady state equilibrium. This can be expressed as the reciprocal value of the steady-state unbound volume of distribution [51].

The IAM MB data were obtained using IAM PC.DD2 HPLC column (Regis Technologies, Inc., II, USA) with the dimensions of $100 \times 3 \mathrm{~mm}$. Mobile phase A was $50 \mathrm{mM}$ ammonium acetate adjusted to $\mathrm{pH} 7.4$, while mobile phase $B$ was $100 \%$ acetonitrile. The flow rate was $1.5 \mathrm{~mL} / \mathrm{min}$, the linear gradient was 0 to $80 \%$ acetonitrile in 0 to $5 \mathrm{~min}, 5$ to $5.25 \mathrm{~min} 80 \%$ acetonitrile then back to $0 \%$ acetonitrile by $5.5 \mathrm{~min}$. The total run time is $7 \mathrm{~min}$. The calibration set of compounds are listed in Table 3 and the calibration test solution is available from Bio-Mimetic Chromatography, UK (www.bio-mimetic-chromatography.com). A typical chromatogram is shown in Figure 2.

It is essential to obtain a straight line between the retention times and the IAM MB index of the calibration set of compounds. Moreover, it is essential to run a system suitability test of compounds (2 neutral, 2 basic and 2 acidic compounds) listed in Table 4, and check that the measured IAM MB data are the same +/- 5 units listed in the table. This ensures that the IAM phospholipid immobilised phase is maintained, preserving the natural phospholipid density on the column.

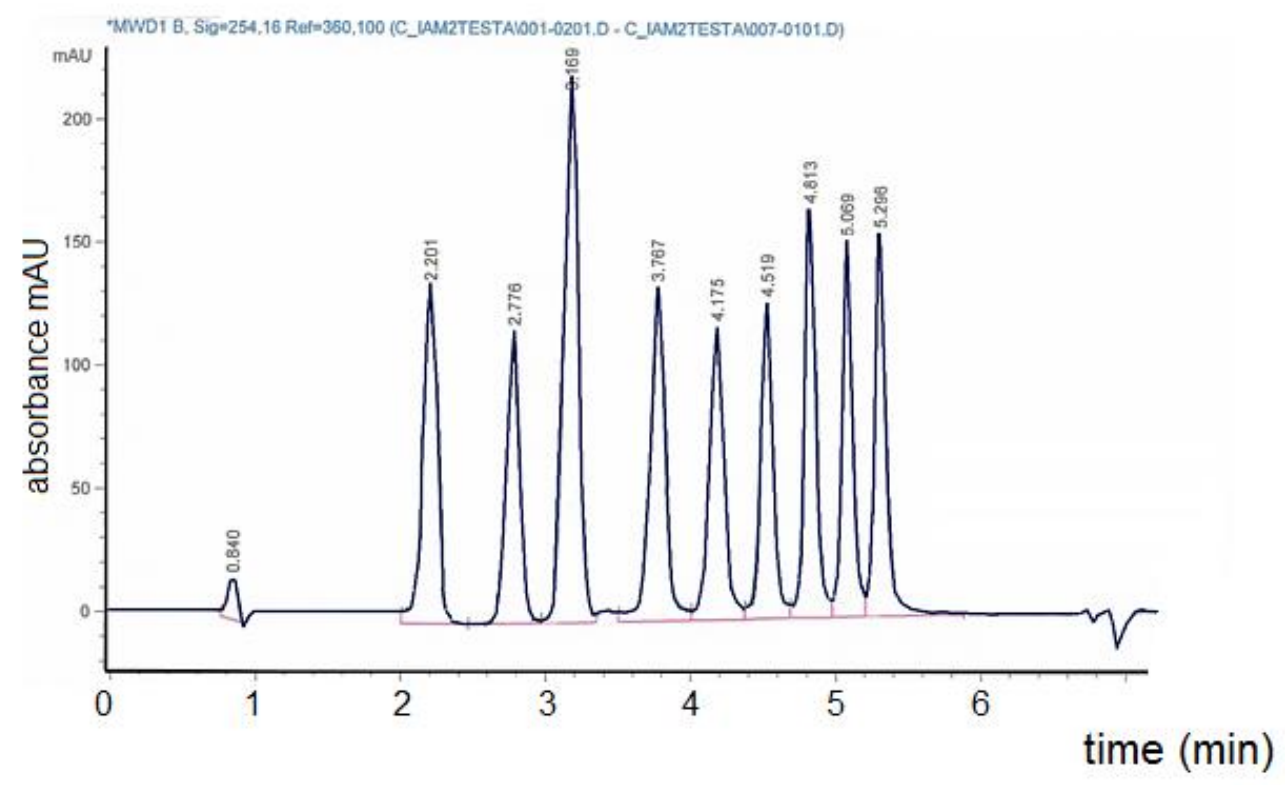

Figure 2. A typical chromatogram obtained on IAM PC.DD2 $100 \times 3 \mathrm{~mm}$ HPLC column. Flow rate: $1.5 \mathrm{~mL} / \mathrm{min}$, mobile phase $A ; 50 \mathrm{mM}$ ammonium acetate adjusted to $\mathrm{pH}$ 7.4, B: acetonitrile. Run time 7 min; Gradient: 0 to $5 \min 0$ to $80 \%$ B, 5 to $5.25 \min 80 \%$ B, 5.25 to $5.5 \min 0 \% \mathrm{~B}$

It was found that the $\log k($ IAM) shows a non-linear relationship with $\log P$ octanol/water values [42]. To convert the $\log k($ IAM) scale to the $\log P$ scale we need the transformation as shown by equation (1). The converted log $K($ IAM) data is equivalent to the partition coefficient of the compound between the $\mathrm{pH} 7.4$ buffer and the phospholipid phase.

$$
\log K(\text { IAM })=0.29 * e^{(0.046 * \mathrm{MB} \text { IAM+0.42)}}+0.70
$$

This data are then be used in the models for the volume of distribution, unbound volume of distribution and the in vitro maximum drug efficiency (HPLC DE $E_{\max }$ ). 
Table 3. The calibration set of compounds and their standard IAM MB score on IAM.PC.DD2 column. The IAM MB data approximate to the acetonitrile concentration in the mobile phase when the compound elutes using the gradient conditions. The log $k(I A M)$ values obtained as $0.046 \mathrm{IAM} \mathrm{MB}+0.42$ where the constants have been derived by plotting isocratic log $k(\mathrm{IAM})$ data extrapolated to $0 \%$ acetonitrile mobile phase using isocratic measurements [52].

\begin{tabular}{|c|c|c|c|}
\hline Compound & Typical $\boldsymbol{t}_{\mathrm{R}}(\mathbf{m i n})$ & IAM MB & log $\boldsymbol{k}(\mathbf{I A M})$ \\
\hline Octanophenone & 3.18 & 49.4 & 2.69 \\
\hline Heptanophenone & 3.07 & 45.7 & 2.52 \\
\hline Hexanophenone & 2.94 & 41.8 & 2.34 \\
\hline Valerophenone & 2.79 & 37.3 & 2.14 \\
\hline Butyrophenone & 2.58 & 32 & 1.89 \\
\hline Propiophenone & 2.35 & 25.9 & 1.61 \\
\hline Acetophenone & 2.04 & 17.2 & 1.21 \\
\hline Acetanilide & 1.85 & 11.5 & 0.95 \\
\hline Paracetamol & 1.62 & 2.9 & 0.55 \\
\hline
\end{tabular}

Table 4. System suitability test compounds and their expected IAM MB data. The measured values should be within 5 IAM MB value agreements with the values in the table. Further drug molecules data can be found in reference [45].

\begin{tabular}{|l|c|c|}
\hline Compound & Acid/base & IAM MB \\
\hline Carbamazepine & Neutral & 26.5 \\
\hline Colchicine & neutral & 18.0 \\
\hline Warfarin & Acidic & 16.0 \\
\hline Indomethacin & Acidic & 24.5 \\
\hline Nicardipine & Basic & 45.1 \\
\hline Propranolol & Basic & 46.8 \\
\hline
\end{tabular}

The PB data are obtained on Chiralpack-HSA and ChiralPack AGP columns with the dimensions of $50 \times 3$ $\mathrm{mm}$. The flow rate was $1.5 \mathrm{~mL} / \mathrm{min}$ and 2-propanol was used as mobile phase $B$, while mobile phase $A$ is 50 $\mathrm{mM}$ ammonium acetate adjusted $\mathrm{pH}$ to 7.4. The calibration set of compounds and their $\log k(\mathrm{HSA})$ and $\log$ $k(A G P)$ data are listed in Table $5 \mathrm{a}$ and $5 \mathrm{~b}$. These data are derived from literature \%HSA and \%AGP binding data obtained by other methodology (equilibrium dialysis and ultrafiltration). These data are used to calibrate the gradient retention times on the protein column so that the binding data obtained from the retention times are comparable with binding data obtained by other methodologies. The typical retention times were obtained using a $6 \mathrm{~min}$ gradient run: 0 to $3 \mathrm{~min} 0$ to $35 \% 2$-propanol, 3 to $4 \mathrm{~min} 35 \% 2$ propanol, 4 to 4.2 min back to $0 \% 2$-propanol. Typical calibration plots and chromatograms have been published previously [14]. It was found that the obtained log $k(\mathrm{HSA})$ showed a non-linear relationship with the $\log P$ values of acetophenone homologues [42]. To convert the $\log k(\mathrm{HSA})$ data to the $\log P$ scale we need to transform them using Equation 2. The so obtained log $K(\mathrm{HSA})$ data are used in the models.

$\log K(\mathrm{HSA})=\mathrm{e}^{\log k(\mathrm{HSA})}$

The published in vivo models used the above-described $\mathrm{MB} / \mathrm{PB}$ data using the following equations below:

$\mathrm{MB} / \mathrm{PB} \log V_{\mathrm{dss}}=0.44 * \log K(\mathrm{IAM})-0.22 * \log K(\mathrm{HSA})-0.66$

$n=179 \quad r^{2}=0.76 \quad s=0.33$ 
where $\mathrm{MB} / \mathrm{PB} \log V_{\mathrm{dss}}$ is the estimated in vivo steady state volume of distribution based on 179 known drugs human clinical data [42].

The model for the unbound volume of distribution has also been published previously using the available data for 70 marketed drugs [43] and shown by Equation 4.

$\mathrm{MB} / \mathrm{PB} \log V_{\mathrm{du}}=0.23 \log K(\mathrm{HSA})+0.43 \log K(\mathrm{IAM})-0.72$

$n=70 r^{2}=0.84 \quad s=0.32$

The HPLC DE $E_{\max }$ data were calculated using the reciprocal value of the MB/PB log $V_{\text {du }}$ data and validated against human clinical $\mathrm{DE}_{\max }$ data [51].

Table 5. The literature \% binding data and the log $k(\mathrm{HSA})(\mathrm{a})$ and $\log k(\mathrm{AGP})(\mathrm{b})$ data for the calibration set of compounds. The logarithmic retention times measured under a given condition should result in a straight line when plotted against the log $k$ data. The regression coefficient should be above 0.96 and the warfarin enantiomers should be baseline separated in order to pass the suitability of the column for protein binding determination.

(a)

\begin{tabular}{|l|c|c|c|c|}
\hline $\begin{array}{c}\text { Bio-Mimetic } \\
\text { Set of compounds }\end{array}$ & $\begin{array}{c}\text { Typical } t_{\mathrm{R}} \\
(\mathrm{min})\end{array}$ & $\log t_{\mathrm{R}}$ & $\begin{array}{c}\text { \% HSA from } \\
\text { literature plasma } \\
\text { protein binding }\end{array}$ & $\begin{array}{c}\log k(\mathrm{HSA}) \\
\text { (as log(\%HSA/(101- } \\
\% \mathrm{HSA})\end{array}$ \\
\hline Warfarin & 3.267 & 0.51 & 97.90 & 1.50 \\
\hline Paracetamol & 0.285 & -0.55 & 14.00 & -0.79 \\
\hline Nizatidine & 0.293 & -0.53 & 20.40 & -0.60 \\
\hline Trimethoprim & 0.512 & -0.29 & 37.60 & -0.23 \\
\hline Propranolol & 0.895 & -0.05 & 66.60 & 0.29 \\
\hline Carbamazepine & 1.216 & 0.08 & 75.00 & 0.46 \\
\hline Nicardipine & 2.374 & 0.38 & 95.00 & 1.20 \\
\hline Indomethacin & 4.117 & 0.61 & 99.50 & 1.82 \\
\hline Diclofenac & 3.879 & 0.59 & 99.80 & 1.92 \\
\hline
\end{tabular}

(b)

\begin{tabular}{|l|c|c|c|c|}
\hline $\begin{array}{c}\text { Bio-Mimetic Chromatography } \\
\text { calibration set of compounds }\end{array}$ & $\begin{array}{c}\text { Typical } \\
t_{\mathrm{R}} \text { min }\end{array}$ & $\log t_{\mathrm{R}}$ & $\begin{array}{c}\text { \%AGP (obtained } \\
\text { by ultrafiltration } \\
\text { [45]) }\end{array}$ & $\begin{array}{c}\text { log } k \text { (AGP) } \\
\text { (expressed from } \\
\text { \%AGP as log } \\
\text { (\%AGP/(101-\%AGP)) }\end{array}$ \\
\hline Warfarin & 3.72 & 0.57 & 83.2 & 0.67 \\
\hline Acetaminophen & 1.16 & 0.06 & 3.2 & -1.49 \\
\hline Nizatidine & 2.19 & 0.34 & 37.1 & -0.24 \\
\hline Trimethoprim & 2.50 & 0.40 & 46.2 & -0.07 \\
\hline Propranolol & 3.86 & 0.59 & 86 & 0.76 \\
\hline Carbamazepine & 3.21 & 0.51 & 73.2 & 0.42 \\
\hline Nicardipine & 4.08 & 0.61 & 92 & 1.01 \\
\hline Indomethacin & 2.98 & 0.47 & 52.9 & 0.04 \\
\hline Diclofenac & 3.09 & 0.49 & 69.3 & 0.34 \\
\hline
\end{tabular}

For the calculation of the stepwise regression equations, the academic version of JMP (SAS Institute) software has been used. The calculation of the physicochemical parameters the Chemaxon and ACD software were used. For creating the plots the Sentira version 1.0.0.6 (Optibrium 2014) software has been used. 


\section{Results and discussion}

The importance of the unbound volume of distribution and the drug efficiency in the drug discovery process has been discussed in several recent papers focusing on the clearance and plasma protein binding [15-16]. There is a general consensus that the free concentration of the compound at the site of action drives clinical efficacy together with the high affinity for the target receptor. However, a significant debate remains regarding what determines the free concentration; the dose, dosing frequency, intrinsic clearance, plasma protein binding or volume of distribution, all are important factors that should be considered. We can depict a simplified model as it was described by Stepensky $[15,61]$ and consider that the dosing amount and frequency required to balance the elimination rate of a compound determines the amount of drug in the body. While the volume of distribution describes how the total amount of drug distributes between the tissue and plasma compartment, unbound volume of distribution describes the drug distribution between the free and bound compartments regardless of the location where the drug binds (tissues or plasma proteins, see Figure 3).

While investigating known drugs it was clear that the volume of distribution showed no correlation alone to clearance or half-life. However, it did show a good correlation with the product term (or the sum of their logarithmic values clearance and half-life) as is shown in Figure $4 a, b$ and $c$. The data supports the statement that the distribution properties of compounds are an independent parameter from the clearance.

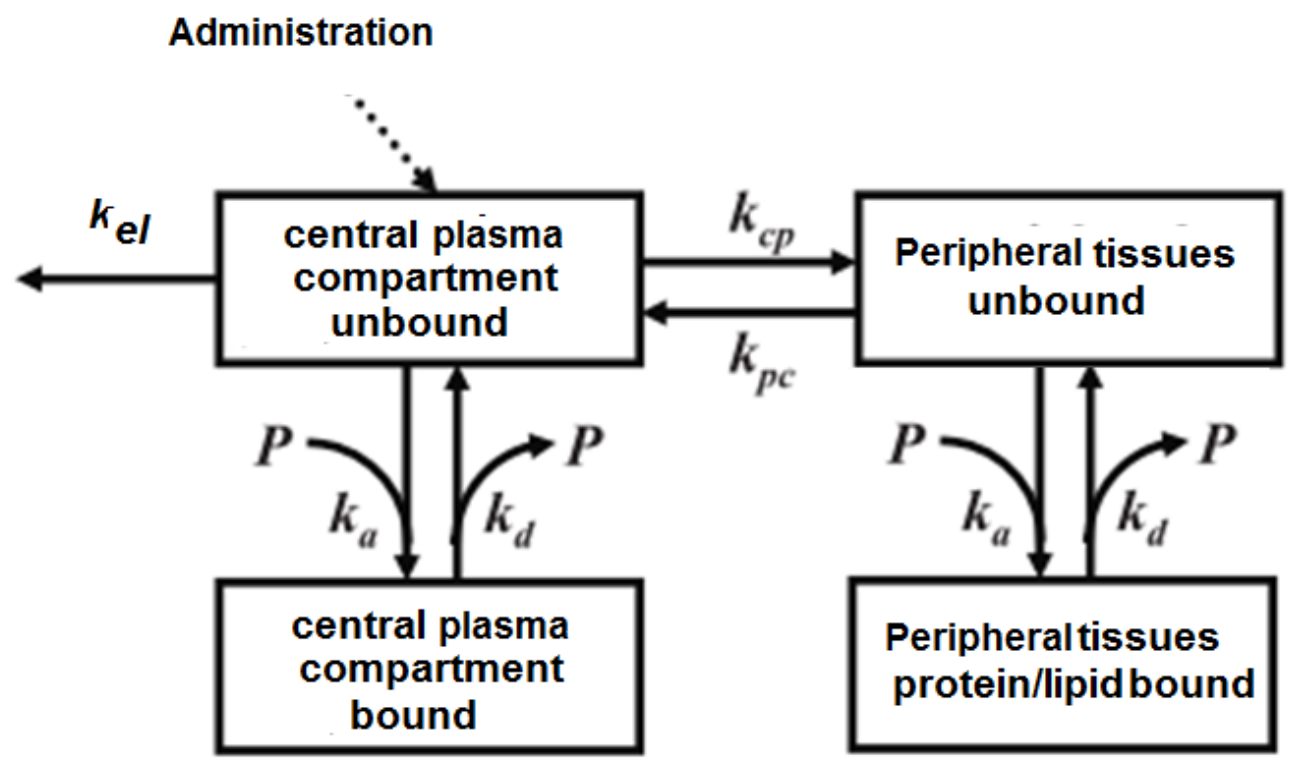

Figure 3. The schematic absorption, distribution and elimination process

The tissue/plasma partition coefficient of a compound can be defined as the tissue concentration divided by the plasma concentration of the compounds. The concentration can be expressed as the amount of drug in the tissue and plasma volume respectively, so $K_{\text {tissue/plasma }}$ can be described by Equation 5 :

$K_{\text {tissue } / \text { plasma }}=\frac{\left(\text { Dose }-A_{p}\right) / V_{t}}{A_{p} / V_{p}}$

where the amount of drug in tissues equals the dose minus the amount in plasma $\left(A_{\mathrm{p}}\right), V_{\mathrm{t}}$ is the tissue volume, $V_{\mathrm{p}}$ is the plasma volume. As the steady-state volume of distribution $\left(V_{\mathrm{dss}}\right)$ equals the dose over the 
plasma concentration, introducing that into Equation 5 we can express the tissue plasma partition as a proportionality term to the steady state volume of distribution shown in Equation 6.

$K_{\text {tissue } / \text { plasma }}=\frac{V d_{s s}-V_{p}}{V_{t}}$

In turn, the volume of distribution of marketed drugs could be modeled by the difference in the membrane and the protein binding of compounds as described by Equation 3 and shown in Figure 5 for the investigated compounds. There are only 40 compounds that have been included in the training set, the majority of the compounds were not included in the original model. That explains that the statistics are slightly worse $\left(r^{2}=0.76\right.$; root mean square error $=0.33$ in the original model, while here the $r^{2}=0.57$ and root mean square error $=0.40)$.

(a)

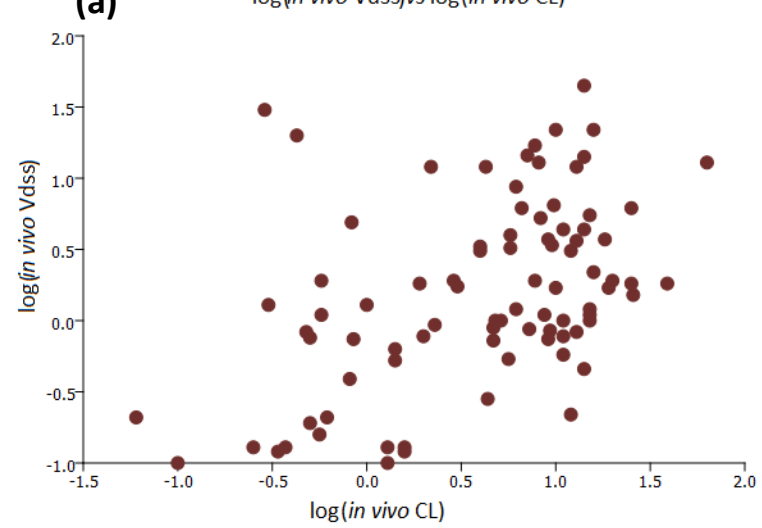

(b) $\quad \log$ (in vivo Vdss) vs (T1/2)

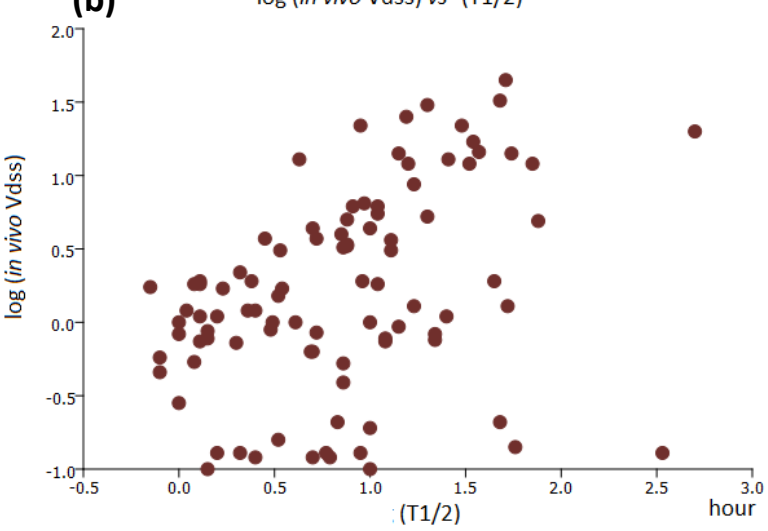

$\log$ (in vivo Vdss) vs est log Vdss from $\mathrm{CL}$ and $\mathrm{T} 1 / 2$

(c)

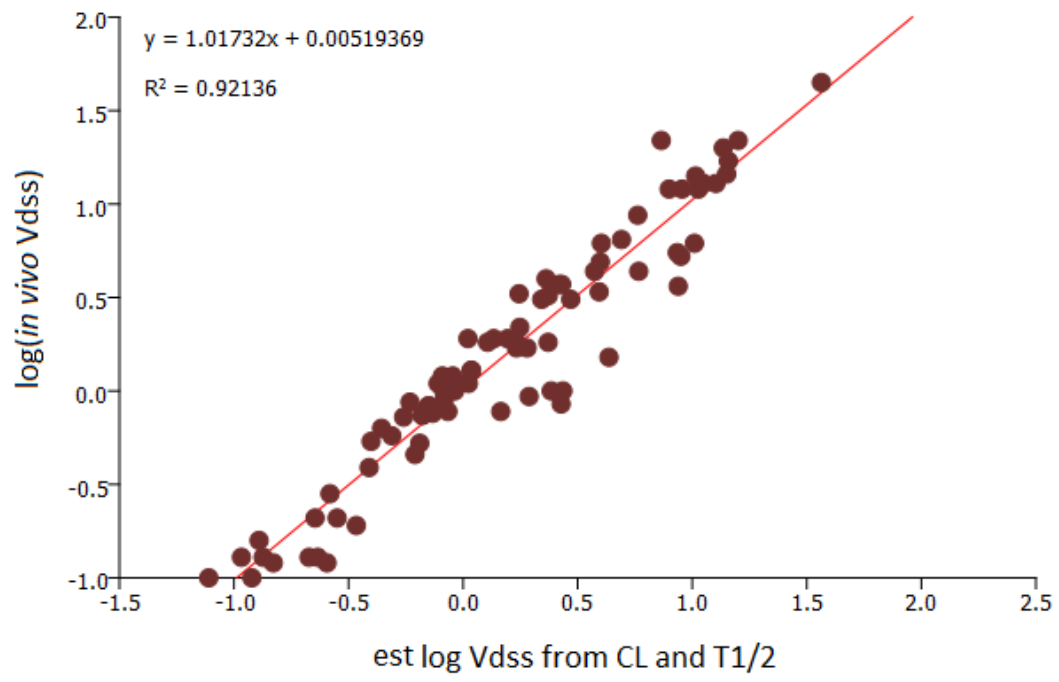

Figure 4. The plot of $\log V_{\mathrm{dss}}$ vs $\log$ in vivo $\mathrm{CL}(\mathrm{a}), \log V_{\mathrm{dss}}$ vs $\log T 1 / 2(\mathrm{~b})$ and $\log V_{\mathrm{dss}}$ vs the sum of $\log \mathrm{CL}$ and $\log$ $T 1 / 2$.

The unbound volume of distribution is in principle the reciprocal value of the maximum drug efficiency $\left(D E_{\max }\right)$ defined by Braggio et al. [18], that is defined by the proportion of the free bio-phase concentration and the dose. If the free drug hypothesis is true, which means the free plasma concentration if similar to 
the free tissue concentration of the compounds when no permeability barrier or active transport distorts the equilibrium, then the model for the unbound volume of distribution can be used to estimate the maximum drug efficiency $\left(D E_{\max }\right.$ ) of the compounds. Based on the definition of the $V_{\mathrm{du}}$ and $D E_{\max }$, their relationship can be described by Equation 7.

$$
D E \max =\frac{100}{V d u}
$$

Figure 6 shows the unbound volume of distribution and the estimated $D E_{\max }$ of the marketed drugs listed in Table A1. In this case, only 10 compounds overlapped with the original training set. Most of the compounds can be considered as a test set. The root-mean-square error increased from 0.32 to 0.45 while the $r^{2}$ dropped from 0.84 to 0.66 . The statistics for the training set is $r^{2}=0.76$ and the standard error of the estimate is $s=0.33$. The estimates can be considered as very predictive, as we have just used two major binding components in the body to describe the total non-specific binding of the compounds to the phospholipids and albumin type of proteins.

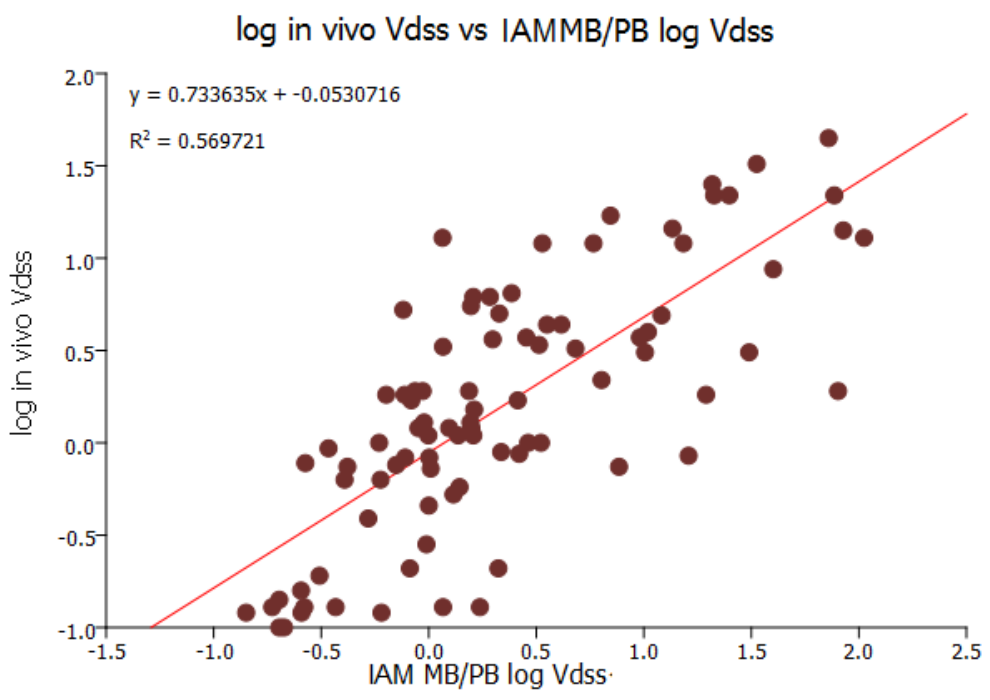

Figure 5. The observed in vivo $\log V_{\mathrm{dss}}$ vs the estimated $V_{\mathrm{dss}}$ by the IAM MB/PB Technology ${ }^{\circledR}$ using Equation 3.

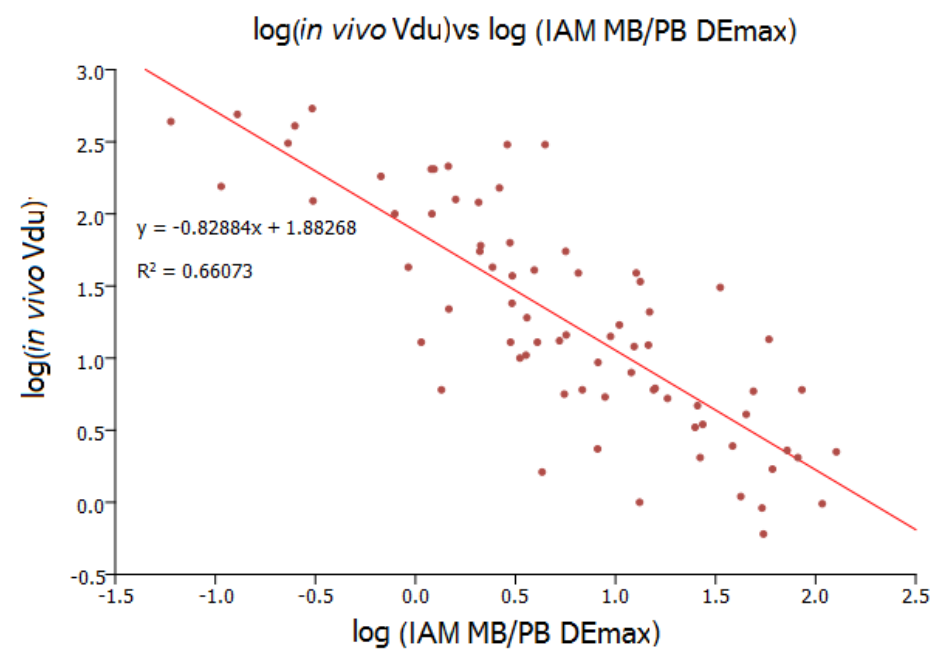

Figure 6. The plot of the human unbound volume of distribution and the estimated $D E_{\max }$ using the IAM $\mathrm{MB} / \mathrm{PB}$ technology and Equation 4. 
It is interesting to observe that the estimated $\mathrm{DE}_{\max }$ of the marketed drugs is typically $1 \%$ or just above. This also means that the unbound volume of distribution of marketed drugs is typically less than $100 \mathrm{~L} / \mathrm{kg}$. Thus, when we plot the potency (pIC50) values in the function of the Drug Efficiency Index (DEI), which is the sum of the pIC50 and the log DE, the marketed drugs are around the line of unity (see Figure 7). It has been observed [51] that discovery compounds usually have very narrow potency range (pIC50 between 7 to 9), but a much broader range of drug efficiency index. Based on the retrospective analysis it turned out that compounds that are on the right side of the line of unity survived the strict candidate selection procedure and showed a good PK/PD profile [51].

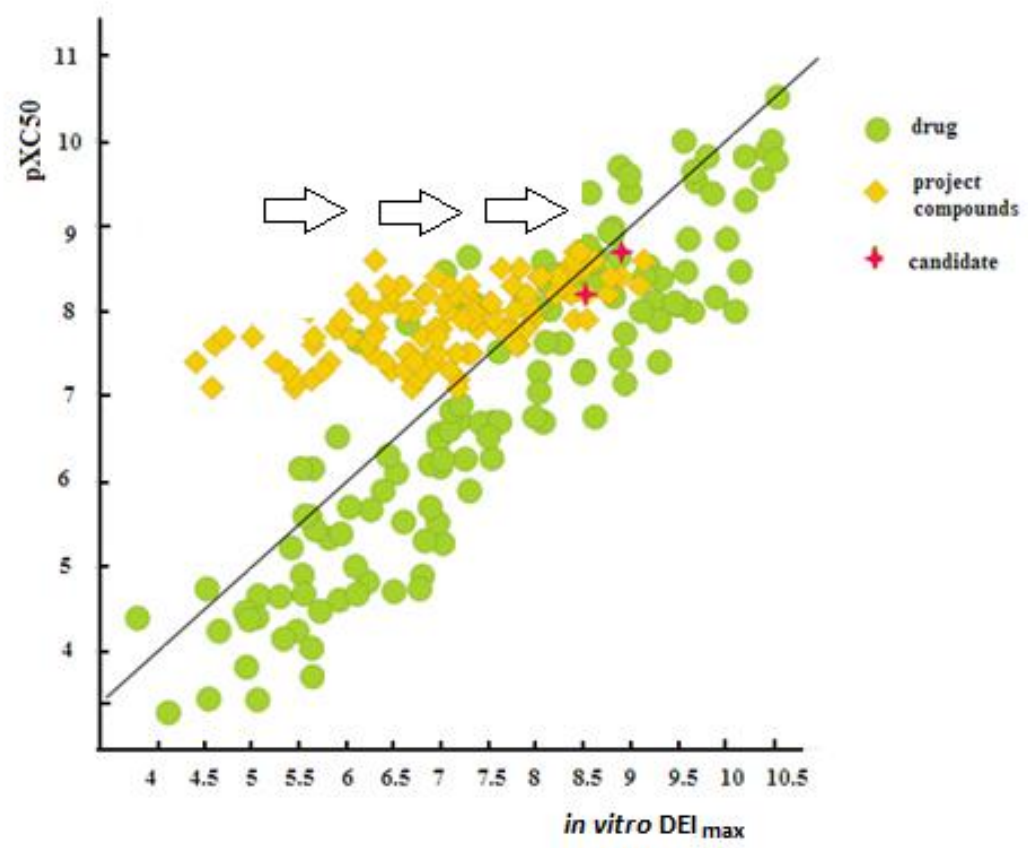

Figure 7. The plot of potency in the function of DEI. The line of unity represents when the drug efficiency $\mathrm{DE}=1 \%$. The logarithm of 1 is zero, thus, DEI = pIC50. The yellow squares show project compounds [51], having the same good potency but a range of DEI. The candidate molecules (red stars) are on the right-hand side of the line where most of the marketed drugs are.

It is interesting to note that we could not find any marketed drugs with drug efficiencies higher than 10$15 \%$. This suggests that there should be an optimum proportion of the dose and free bio-phase concentration that is less than 10-15\% drug efficiency. It is very likely, that when the high proportion of the administered amount of compound is free then the elimination rate/clearance will be high and the various total tissue concentrations may be low. Therefore, we can optimise drug discovery compounds and triage them to have reasonably good potency if the drug efficiency is approximately 1 to $5 \%$.

The Regis IAM MB/PB Technology ${ }^{\circledR}$ that use biomimetic HPLC stationary phases to measure the dynamic equilibrium constants of the compounds with the major binding components of the body enables the estimation of volume distribution and unbound volume of distribution without using in vivo experimentation for the fraction of the cost and time.

It is also interesting to note that the DEmax values representing the sum of the albumin and phospholipid binding showed very good inverse correlation with $\operatorname{cog} P$ (much better than with $\operatorname{cog} D$ ) [51]. This is because the $\log D$ drops whatever charge is present on the molecule at $\mathrm{pH} 7.4$, however the sum of albumin and phospholipid binding change very little with the presence of charge. It is because positively charged compounds bind more strongly to IAM (phospholipids) while negatively charged compounds have 
a stronger affinity to albumin type of proteins. That is why $\log P$ is a better model to use than $\log D$ [51]. Therefore, there is a connection between DEI and LLE. DE $E_{\max }$ determined by the IAM MB/PB Technology is a better representation of the nonspecific binding of the compounds than $\log P$ as it is based on real albumin and IAM affinity of the compounds. In our earlier paper, we have shown that IAM MB/PB DEI $\left.\right|_{\max }$ showed a better correlation with in vivo log DEI $I_{\max }$ than LLE as it shown in Figure 8a and $8 \mathrm{~b}$.

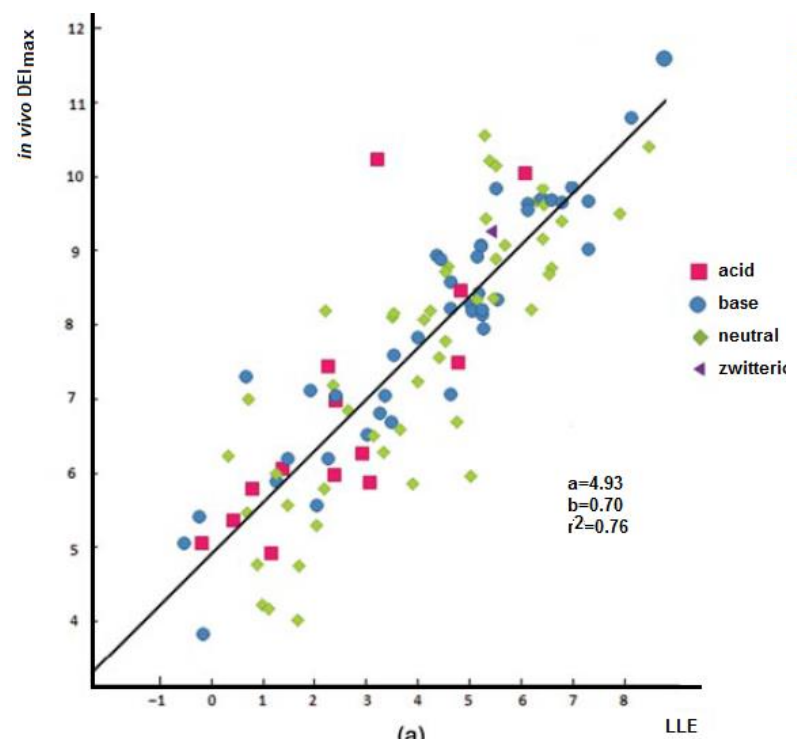

(a)

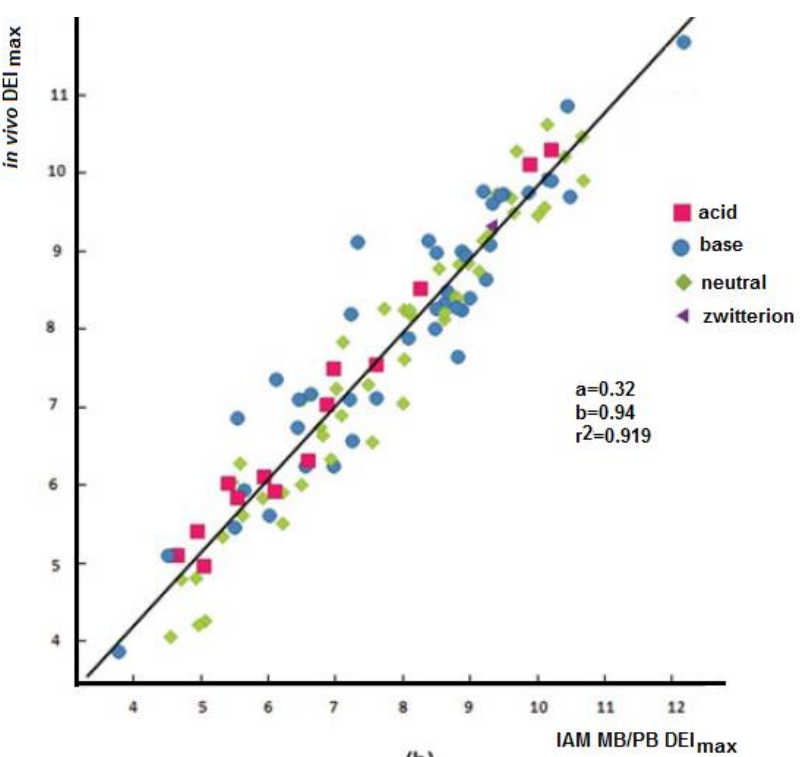

(b)

Figure 8. Comparison of the relationship between in vivo log $D E I_{\max } v s L L E(a)$ and $I A M M B / P B \log D E I_{\max }(b)$, respectively based on the analysis in reference [51].

The better fit is not surprising, as log $P$ was intended to model the non-specific binding in the body caused by lipophilicity of the compounds. The IAM MB/PB technology provides the direct measurements of the major types of body components. Though AGP was not used in the models described above, it is mainly due to statistical reasons. The AGP binding and IAM MB binding showed a significant correlation, so it was not possible to use both as independent variables in the regression equations. AGP binds also the positively charged compounds, however, there is a different steric hindrance for molecules that have bulky substitutions near the positive charge [62]. Although AGP can be found in human plasma at low concentrations (approximately $1.5 \%$ ) it may be significant in clinical investigations as its concentration depends on the disease state and can increase significantly [63]. Therefore compounds' strong binding to AGP should be avoided as it may cause variable free concentrations of the drug in patients with various diseases. The model to estimate total plasma protein binding ( $\log k(\mathrm{PPB}))$ includes the AGP binding as is shown by Equation 8 [64].

$$
\begin{aligned}
& \log k(P P B)=0.87 * \log k(H S A)+0.17 * \log k(A G P)+0.06 * c M R-0.27 \\
& \mathrm{n}=55 \quad \mathrm{r}^{2}=0.85 \quad \mathrm{~s}=0.36
\end{aligned}
$$

CMR is the calculated molar refraction of the compounds related to the size of the molecules and accounts for the non-specific binding of the compounds to immunoglobulins in the plasma.

AGP also represents important cellular components such as glycoprotein in general. There has been observed overlapping binding between AGP and P-glycoprotein [65]. Also, the mucus in human airways is composed predominantly of glycoproteins. Several tissue binding models include the AGP binding, such as 
mucus binding showed good correlation to AGP binding $\left(r^{2}=0.85\right)$ [66] and lung tissue binding showed good correlations with the weighted sum of HSA and AGP bindings [67].

\section{Conclusions}

Established screening procedures in pharmaceutical drug discovery companies cause significant delays in getting a compound to market. One reason is that the initial discovery phase typically prioritises optimising discovery molecules to bind with high affinity to the target receptor. Drug analogues typically possess high receptor occupancy, which is anticipated to have better efficacy and selectivity, i.e., reduced off-target pharmacology. The insight lacking during this process is that all the potent analogues may not have the ADME properties to elicit sufficient free concentration of the drug near the receptor. We have presented an HPLC based technology by which the drug discovery process can be accelerated by chromatographic profiling of the analogues to model the in vivo drug disposition. The proposed methodology is able to identify compounds that have a greater probability of having acceptable in vivo properties. The methodology has been compared to Ligand Lipophilicity Efficiency (LLE) parameter that is used early in the lead optimization process. There is an inverse correlation between the maximum drug efficiency and $\operatorname{cog} P$, thus LLE incorporates similar efficiency metrics as DEl. While clog $P$ can be easily calculated and the drug efficiency requires simple HPLC based measurements, the advantage is that it mimics the biological non-specific binding more accurately than calculated octanol/water lipophilicity. The measured IAM MB/PB incorporates the effect of charge and shape of the molecules on the binding to real body components which are not reflected in their distribution in octanol and water. The technology is suitable for estimating the tissue binding, plasma protein binding, volume of distribution, unbound volume of distribution, drug efficiency, promiscuity, phospholipidotic potential, etc. Therefore, this technology is recommended for use in early drug discovery programmes to aid the compound triage process so that only compounds with a higher probability of having good affinity along with good ADME properties are selected for progression to expensive animal studies. The technology is commercially available; the models have been published in a book titled "Physicochemical and Biomimetic Properties in Drug Discovery: Chromatographic Techniques for Lead Optimisation" [45] and are encouraged to be routinely used in the early drug discovery process.

The conclusion is that in vivo data should not be generated until the compounds have been analysed by chromatographic techniques, and only compounds that are predicted to have optimal in vivo properties should be progressed for further analysis. The proposed alternate drug discovery process should include (i) potency evaluation or receptor binding and (ii) predictive in vivo properties of each analogues. Only after both of these steps are completed should compounds be chosen for further development by extensive testing both in vitro and in vivo. Using this approach will eliminate numerous candidates from the pool of active analogues and has the potential to help save considerable amounts of time and money during the process of getting NCE's to market. Even if only 5-10 compounds are immediately eliminated as drug candidates, this potentially saves millions of dollars in the cost to get a drug to market.

\section{References}

[1] E. Perola. J. Med. Chem. 53(7) (2010) 2986-2997.

[2] A. Cheng, D.J. Diller, S.L. Dixon, W.J. Egan, G. Lauri, K.M. Merz. J. Comput. Chem. 23(1) (2002) 172183.

[3] H. Van de Waterbeemd, D.A. Smith, K. Beaumont, D.K. Walker. J. Med. Chem. 44(9) (2001) 13131333.

[4] I. Collins, P. Workman. Nat. Chem. Biol. 2(12) (2006) 689-700. 
[5] A. Avdeef. ADMET DMPK 3(2) (2015) 84-109.

[6] J. Hughes, S. Rees, S. Kalindjian, K. Philpott. Br. J. Pharmacol. 162(6) (2011) 1239-1249.

[7] C.W. Murray, D.A. Erlanson, A.L. Hopkins, G.M. Keserü, P.D. Leeson, D.C. Rees, C.H. Reynolds, N.J. Richmond. ACS Med. Chem. Lett. 5(6) (2014) 616-618.

[8] A.L. Hopkins, G.M. Keserü, P.D. Leeson, D.C. Rees, C.H. Reynolds. Nature Rev. Drug Discov. 13(2) (2014) 105-121.

[9] J.D. Hughes, J. Blagg, D.A. Price, S. Bailey, G.A. DeCrescenzo, R.V. Devraj, et al. Bioorg. Med. Chem. Lett. 18(17) (2008) 4872-4875.

[10] A.A. Nava-Ocampo, A.M. Bello-Ramírez. Clin. Exp. Pharmacol. Physiol. 31 (2004) 116-118.

[11] N.A. Meanwell. Chem. Res. Toxicol. 24(9) (2011) 1420-1456.

[12] T.J. Ritchie, S.J.F. Macdonald. Drug Discov. Today 14(21-22) (2009) 1011-1020.

[13] D. Smith, E.F. Schmid. Curr. Opin. Drug Discov. Devel. 9(1) (2006) 38-46.

[14] K.L. Valkó. J. Pharm. Biomed. Anal. 130 (2016) 35-54.

[15] D. Stepensky. Eur. J. Pharm. Sci. 42(1-2) (2011) 91-98.

[16] D.A. Smith, L. Di, E.H. Kerns. Nat. Rev. Drug Discov. 9(12) (2010) 929-939.

[17] P.D. Dobson, D.B. Kell. Nat. Rev Discov. 7(3) (2008) 205-20.

[18] S. Braggio, D. Montanari, T. Rossi, E. Ratti. Expert Opin. Drug Discov. 5 (2010) 609-618.

[19] D. Montanari, E. Chiarparin, M.P. Gleeson, S. Braggio, R. Longhi, K. Valko K, et al. Expert Opin. Drug Discov. 6(9) (2011) 913-920.

[20] K.A. Youdim, A. Avdeef, N.J. Abbott. Drug Discov. Today 8(21) (2003) 997-1003.

[21] E.M. del Amo, L. Ghemtio, H. Xhaard, M. Yliperttula, A. Urtti, H. Kidron. PLOS One 8(10) (2013) 1-12.

[22] P. Thansandote, R.M. Harris, H.L. Dexter, G.L. Simpson, S. Pal, R.J. Upton, et al. Bioorg. Med. Chem. 23(2) (2015) 322-327.

[23] P.D. Leeson, B. Springthorpe. Nat. Rev. Drug Discov. 6(11) (2007) 881-890.

[24] B. Testa, P. Crivori, M. Reist, P. Carrupt. Perspect. Drug Discovery Des. 19 (2000) 179-211.

[25] L. Huang, L. Berry, S. Ganga, B. Janosky, A. Chen, J. Roberts, et al. Drug Metab. Dispos. 38(2) (2010) 223-331.

[26] G.M. Keserü, G.M. Makara. Nat. Rev. Drug Discov. 8(3) (2009) 203-212.

[27] R.J. Young, D.V.S. Green, C.N. Luscombe, A.P. Hill. Drug Discov. Today 16(17-18) (2011) 822-830.

[28] C. Hansch, T. Fujita. p - $\sigma-\pi$ Analysis. J. Am. Chem. Soc. 86(8) (1964) 1616-1626.

[29] M.D. Donovan. J. Womens Health 14(1) (2005) 30-37.

[30] J. Faulkner, D. McGibney, L. Chasseaud, J. Perry, I. Taylor. Br. J. Clin. Pharmacol. 22(1) (1986) 21-25.

[31] C. Pidgeon, S. Ong, H. Choi, H. Liu. Anal. Chem. 66(17) (1994) 2701-2709.

[32] C.Y. Yang, S.J. Cai, H. Liu, C. Pidgeon. Adv. Drug Deliv. Rev. 23(96) (1996) 229-256.

[33] C. Pidgeon. EP0408585A1 Immobilized Artificial Membranes, Int Pub Patent No WO 89/08/30, Filing: 21 February 1989.

[34] S.K. Wiedmer, M.L. Riekkola, M.S. Jussila. Trends Anal. Chem. 23(8) (2004) 562-582.

[35] Y. Kumada, M. Nogami, N. Minami, M. Maehara, S. Katoh. J. Chromatogr. A 1080(1) (2005) 22-28.

[36] X.Y. Liu, Q. Yang, N. Kamo, J. Miyake. J. Chromatogr. A 913 (2001) 123-131.

[37] K. Valko, S. Nunhuck, C. Bevan, M.H. Abraham, D.P. Reynolds. J. Pharm. Sci. 92(11) (2003) 2236-2248.

[38] J. Reilly, D. Etheridge, B. Everatt, Z. Jiang, C. Aldcroft, P. Wright, et al. J. Liq. Chromatogr. Relat. Technol. 34(4) (2011) 317-327.

[39] F. Beaudry, M. Coutu, N.K. Brown. Biomed. Chromatogr. 13(6) (1999) 401-406.

[40] M. Chrysanthakopoulos, T. Vallianatou, C. Giaginis, A. Tsantili-Kakoulidou. Eur. J. Pharm. Sci. 60 (2014) 24-31.

[41] S. Taheri, L.P. Cogswell, A. Gent, G.R. Strichartz. J. Pharmacol. Exp. Ther. 304(1) (2003) 71-80. 
[42] F. Hollosy, K. Valko, A. Hersey, S. Nunhuck, G. Keri, C. Bevan, et al. J. Med. Chem. 49(24) (2006) 69586971.

[43] K.L. Valkó, S.B. Nunhuck, A.P. Hill. J. Pharm. Sci. 100(3) (2011) 849-862.

[44] X. Zhao, W. Chen, Z. Zhou, Q. Wang, Z. Liu, R. Moaddel, et al. J. Chromatogr. A 1407 (2015) 176-183.

[45] K. Valko. Physicochemical and Biomimetic Properties in Drug Discovery: Chromatographic techniques for Lead Optimization. Wiley Hoboken NJ; 2014. 226 p.

[46] K.M. Wasan, D.R. Brocks, S.D. Lee, K. Sachs-Barrable, S.J. Thornton. Nat. Rev. Drug Discov. 7(1) (2008) 84-99.

[47] A. Casartelli, M. Bonato, P. Cristofori, F. Crivellente, G. Dal Negro, I. Masotto, et al. Cell Biol. Toxicol. 19(3) (2003) 161-176.

[48] L.J. Gordon, M. Allen, P. Artursson, M.M. Hann, B.J. Leavens, A. Mateus, et al. J. Biomol. Screen. 21(2) (2016) 156-164.

[49] K.M. Page. Mol. Pharm. 13(2) (2016) 609-620.

[50] K. Tam. ADMET DMPK 1(4) (2013) 63-75.

[51] K. Valko, E. Chiarparin, S. Nunhuck, D. Montanari. J. Pharm. Sci. 101(11) (2012) 4155-4169.

[52] K. Valko, C.M. Du, C.D. Bevan, D.P. Reynolds, M.H. Abraham, J. Pharm. Sci. 89(8) (2000) 1085-1096.

[53] G. Russo, L. Grumetto, F. Barbato, G. Vistoli, A. Pedretti. Eur. J. Pharm. Sci. 99 (2017) 173-184.

[54] G. Colmenarejo. Med. Res. Rev. 23(3) (2003) 275-301.

[55] G. Lambrinidis, T. Vallianatou, A. Tsantili-Kakoulidou. Adv. Drug Deliv. Rev. 86 (2015) 27-45.

[56] P.N. Mortenson, C.W. Murray. J. Comput. Aided Mol. Des. 25(7) (2011) 663-667.

[57] U.M. Hanumegowda, G. Wenke, A. Regueiro-Ren, R. Yordanova, J.P. Corradi, S.P. Adams. Chem. Res. Toxicol. 23(4) (2010) 749-755.

[58] D. Price, J. Blagg, L. Jones, N. Greene, T. Wager. Expert Opin. Drug Metab. Toxicol. 5(8) (2009) 921931.

[59] A. Casartelli, A. Lanzoni, R. Comelli, F. Crivellente, R. Defazio, R. Dorigatti, et al. Toxicol. Pathol. 39(2) (2011) 361-371.

[60] L.J. Gordon, M. Allen, P. Artursson, M.M. Hann, B.J. Leavens, A. Mateus, et al. J. Biomol. Screen. 21(2) 2016 156-164.

[61] D. Stepensky. Expert Opin. Drug Metab. Toxicol. 7(10) (2011) 1233-1243.

[62] R. Kaliszan, A. Nasal, M. Turowski. Biomed. Chromatogr. 9(5) (1995) 211-215.

[63] T. Fournier, N. Medjoubi, D. Porquet. Biochim. Biophys. Acta 1482 (2000) 157-171.

[64] K. Valko. Physicochemical and Biomimetic Properties in Drug Discovery: Chromatographic Techniques for Lead Optimization. Wiley Hoboken NJ, (2014), Chapter 11, p. 294-310.

[65] F. Zsila. Curr. Drug Metab. 8 (2007) 563-593.

[66] K. Valko. Physicochemical and Biomimetic Properties in Drug Discovery: Chromatographic Techniques for Lead Optimization. Wiley Hoboken NJ, (2014) Chapter 11, p. 295.

[67] K. Valko. Physicochemical and Biomimetic Properties in Drug Discovery: Chromatographic Techniques for Lead Optimization. Wiley Hoboken NJ, (2014), Chapter 11, p. 296. 


\section{Appendix}

Table A1. The in vivo human data for the investigated marketed drugs. Training set marked from the $V_{\mathrm{d}}$ model [42].

\begin{tabular}{|c|c|c|c|c|c|c|c|c|c|c|c|c|}
\hline DRUG & 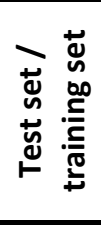 & $\frac{\substack{\frac{\pi}{\pi} \\
\frac{\pi}{0}}}{\frac{\pi}{\pi}}$ & $\begin{array}{c}\text { plC } \\
50\end{array}$ & 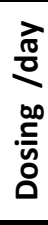 & 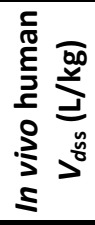 & 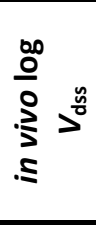 & 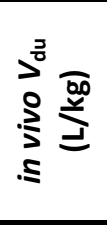 & 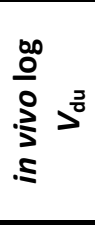 & 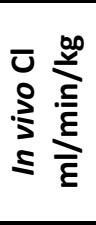 & 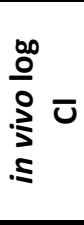 & $t_{1 / 2}(h)$ & $\begin{array}{l}\text { Log } \\
t_{1 / 2} \\
\text { (h) }\end{array}$ \\
\hline ABACAVIR & Test & 600 & 7.2 & 2 & 0.84 & -0.08 & 1.68 & 0.23 & 13.00 & 1.11 & 1.00 & 0.00 \\
\hline $\begin{array}{l}\text { ACEBUTOLOL } \\
\text { HYDROCHLORIDE }\end{array}$ & Test & 400 & 6.8 & 2 & 1.7 & 0.23 & 2.30 & 0.36 & 10.00 & 1.00 & 3.50 & 0.54 \\
\hline $\begin{array}{l}\text { ACETYLSALICYLIC } \\
\text { ACID }\end{array}$ & Train. & 1200 & 5.5 & 3 & 0.22 & -0.66 & 0.32 & -0.49 & 12.00 & 1.08 & & \\
\hline ACRIVASTINE & Test & 32 & 8.5 & 4 & & & & & & & 1.50 & 0.18 \\
\hline $\begin{array}{l}\text { ALBUTEROL } \\
\text { SULFATE }\end{array}$ & Test & 8 & 7.4 & 4 & 1.9 & 0.28 & 2.07 & 0.31 & 7.80 & 0.89 & 2.40 & 0.38 \\
\hline ALLOPURINOL & Test & 300 & 5.3 & 1 & 0.58 & -0.24 & 0.60 & -0.22 & 11.00 & 1.04 & 0.80 & -0.10 \\
\hline $\begin{array}{l}\text { ALOSETRON } \\
\text { HYDROCHLORIDE }\end{array}$ & Train. & 1 & 7.3 & 2 & 1.1 & 0.04 & 6.11 & 0.79 & 8.70 & 0.94 & 1.60 & 0.20 \\
\hline $\begin{array}{l}\text { AMILORIDE } \\
\text { HYDROCHLORIDE }\end{array}$ & Test & 5 & 5.5 & 1 & 5 & 0.70 & & & & & 7.50 & 0.88 \\
\hline $\begin{array}{l}\text { AMINO- } \\
\text { GLUTETHIMIDE }\end{array}$ & Test & 500 & 4.9 & 2 & & & & & & & 12.50 & 1.10 \\
\hline $\begin{array}{l}\text { AMITRIPTYLINE } \\
\text { HYDROCHLORIDE }\end{array}$ & Test & 50 & 6.2 & 1 & 8.7 & 0.94 & 124.29 & 2.09 & 6.10 & 0.79 & 17.00 & 1.23 \\
\hline AMOXAPINE & Train. & 300 & 6.5 & 3 & & & & & & & & \\
\hline ARIPIPRAZOLE & Test & 10 & 9.7 & 1 & 4.9 & 0.69 & 490.00 & 2.69 & 0.83 & -0.08 & 75.00 & 1.88 \\
\hline $\begin{array}{l}\text { ATOMOXETINE } \\
\text { HYDROCHLORIDE1 }\end{array}$ & Test & 40 & 8.7 & 1 & 0.85 & -0.07 & 42.50 & 1.63 & 9.30 & 0.97 & 5.20 & 0.72 \\
\hline $\begin{array}{l}\text { BENDRO- } \\
\text { FLUMETHIAZIDE }\end{array}$ & Test & 3 & 3.4 & 1 & & & & & & & 8.50 & 0.93 \\
\hline BICALUTAMIDE & Test & 50 & 6.1 & 1 & & & & & & & 144.00 & 2.16 \\
\hline $\begin{array}{l}\text { BUPROPION } \\
\text { HYDROCHLORIDE }\end{array}$ & Test & 300 & 6.3 & 1 & & & & & & & 24.00 & 1.38 \\
\hline CABERGOLINE & Test & 0 & 10 & 0 & & & & & 45.71 & 1.66 & 65.00 & 1.81 \\
\hline CAFFEINE & Test & 150 & 4.7 & 3 & 0.63 & -0.20 & 0.98 & -0.01 & 1.40 & 0.15 & 4.90 & 0.69 \\
\hline $\begin{array}{l}\text { CANDESARTAN } \\
\text { CILEXETIL }\end{array}$ & Test & 8 & 10.5 & 1 & 0.13 & -0.89 & 13.00 & 1.11 & 0.37 & -0.43 & 9.00 & 0.95 \\
\hline CARBAMAZEPINE & Train. & 800 & 4.6 & 1 & & & & & & & 17.00 & 1.23 \\
\hline CELECOXIB & Test & 400 & 8.5 & 2 & 6.13 & 0.79 & 204.33 & 2.31 & 6.59 & 0.82 & 11.00 & 1.04 \\
\hline CILOSTAZOL & Test & 200 & 6.7 & 2 & & & & & & & 12.00 & 1.08 \\
\hline $\begin{array}{l}\text { CITALOPRAM } \\
\text { HYDROBROMIDE }\end{array}$ & Test & 20 & 8.3 & 1 & 12 & 1.08 & 60.00 & 1.78 & 4.30 & 0.63 & 33.00 & 1.52 \\
\hline $\begin{array}{l}\text { CLOMIPRAMINE } \\
\text { HYDROCHLORIDE }\end{array}$ & Test & 25 & 7.9 & 1 & 13 & 1.11 & 433.33 & 2.64 & 8.20 & 0.91 & 26.00 & 1.41 \\
\hline $\begin{array}{l}\text { CLONIDINE } \\
\text { HYDROCHLORIDE }\end{array}$ & Train. & 0 & 8.5 & 1 & 3.3 & 0.52 & 5.89 & 0.77 & 4.00 & 0.60 & 7.60 & 0.88 \\
\hline DAPSONE & Test & 100 & 4.8 & 1 & 0.83 & -0.08 & 3.32 & 0.52 & 0.48 & -0.32 & 22.00 & 1.34 \\
\hline DESLORATADINE & Test & 5 & 9.4 & 1 & & & & & & & 50.00 & 1.70 \\
\hline
\end{tabular}




\begin{tabular}{|c|c|c|c|c|c|c|c|c|c|c|c|c|}
\hline DIAZOXIDE & Train. & 150 & 4.7 & 3 & 0.21 & -0.68 & 3.50 & 0.54 & 0.06 & -1.22 & 48.00 & 1.68 \\
\hline DIDANOSINE & Test & 250 & 8 & 2 & 0.77 & -0.11 & 0.81 & -0.09 & 11.00 & 1.04 & 1.40 & 0.15 \\
\hline DIFLUNISAL & Train. & 1000 & 4.2 & 2 & 0.1 & -1.00 & & & 0.10 & -1.00 & 10.00 & 1.00 \\
\hline $\begin{array}{l}\text { DIPHENHYDRAMINE } \\
\text { HYDROCHLORIDE }\end{array}$ & Train. & 75 & 8.1 & 3 & 6.5 & 0.81 & 34.21 & 1.53 & 9.80 & 0.99 & 9.30 & 0.97 \\
\hline DIPYRIDAMOLE & Train. & 200 & 6.7 & 2 & 1.75 & 0.24 & 175.00 & 2.24 & 3.00 & 0.48 & 0.70 & -0.15 \\
\hline DOMPERIDONE & Test & 30 & 9.8 & 3 & 3.4 & 0.53 & 42.50 & 1.63 & 9.50 & 0.98 & 7.50 & 0.88 \\
\hline $\begin{array}{l}\text { DONEPEZIL } \\
\text { HYDROCHLORIDE }\end{array}$ & Test & 5 & 8.2 & 1 & 12 & 1.08 & 300.00 & 2.48 & 2.17 & 0.34 & 70.00 & 1.85 \\
\hline EFAVIRENZ & Test & 600 & 8.9 & 1 & & & & & & & 47.00 & 1.67 \\
\hline ETODOLAC & Test & 600 & 6.2 & 2 & 0.39 & -0.41 & 39.00 & 1.59 & 0.82 & -0.09 & 7.30 & 0.86 \\
\hline FELBAMATE & Train. & 1200 & 3.4 & 3 & 0.76 & -0.12 & 1.09 & 0.04 & 0.50 & -0.30 & 22.00 & 1.34 \\
\hline FELODIPINE & Train. & 5 & 9.8 & 1 & 4.4 & 0.64 & & & 11.00 & 1.04 & 10.00 & 1.00 \\
\hline $\begin{array}{l}\text { FEXOFENADINE } \\
\text { HYDROCHLORIDE }\end{array}$ & Test & 60 & 7.3 & 2 & & & & & & & 14.40 & 1.16 \\
\hline FINASTERIDE & Train. & 5 & 7.3 & 1 & 0.89 & -0.05 & 5.56 & 0.75 & 4.70 & 0.67 & 3.00 & 0.48 \\
\hline $\begin{array}{l}\text { FLUOXETINE } \\
\text { HYDROCHLORIDE }\end{array}$ & Train. & 60 & 8.6 & 1 & 32.5 & 1.51 & 541.67 & 2.73 & & & 48.00 & 1.68 \\
\hline FLURBIPROFEN & Train. & 200 & 6.2 & 4 & 0.12 & -0.92 & & & & & 5.00 & 0.70 \\
\hline FLUTAMIDE & Test & 750 & 5.9 & 3 & & & & & & & 6.00 & 0.78 \\
\hline $\begin{array}{l}\text { FLUVOXAMINE } \\
\text { MALEATE }\end{array}$ & Test & 50 & 8.3 & 1 & 25 & 1.40 & 125.00 & 2.10 & & & 15.60 & 1.19 \\
\hline FUROSEMIDE & Train. & 80 & 5 & 2 & 0.12 & -0.92 & 12.00 & 1.08 & 1.60 & 0.20 & 2.50 & 0.40 \\
\hline GLIBENCLAMIDE & Test & 3 & 5.3 & 1 & 0.13 & -0.89 & 13.00 & 1.11 & 1.30 & 0.11 & 1.60 & 0.20 \\
\hline GLIMEPIRIDE & Test & 1 & 5.4 & 1 & 0.19 & -0.72 & 19.00 & 1.28 & 0.50 & -0.30 & 10.00 & 1.00 \\
\hline GLIPIZIDE & Train. & 3 & 5.5 & 1 & 0.16 & -0.80 & 8.00 & 0.90 & 0.56 & -0.25 & 3.30 & 0.52 \\
\hline $\begin{array}{l}\text { GRANISETRON } \\
\text { HYDROCHLORIDE }\end{array}$ & Test & 2 & 9.9 & 2 & 3.7 & 0.57 & 10.57 & 1.02 & 9.10 & 0.96 & 5.20 & 0.72 \\
\hline $\begin{array}{l}\text { GUANABENZ } \\
\text { ACETATE }\end{array}$ & Test & 8 & 8.2 & 2 & & & & & & & 6.00 & 0.78 \\
\hline HALOPERIDOL & Test & 2 & 10 & 2 & 17 & 1.23 & 212.50 & 2.33 & 7.80 & 0.89 & 35.00 & 1.54 \\
\hline $\begin{array}{l}\text { HYDROCHLOROTHIA } \\
\text { ZIDE }\end{array}$ & Test & 50 & 4.7 & 2 & & & & & & & 8.00 & 0.90 \\
\hline $\begin{array}{l}\text { IMIPRAMINE } \\
\text { HYDROCHLORIDE }\end{array}$ & Train. & 75 & 6.6 & 1 & 12 & 1.08 & 150.00 & 2.18 & 13.00 & 1.11 & 16.00 & 1.20 \\
\hline INDAPAMIDE & Test & 1 & 4.2 & 1 & & & & & & & 14.00 & 1.15 \\
\hline INDOMETHACIN & Train. & 75 & 6.5 & 3 & 0.1 & -1.00 & 10.00 & 1.00 & 1.30 & 0.11 & 1.40 & 0.15 \\
\hline IRBESARTAN & Test & 150 & 9.3 & 1 & 0.94 & -0.03 & 9.40 & 0.97 & 2.30 & 0.36 & 14.00 & 1.15 \\
\hline ISRADIPINE & Test & 5 & 6.6 & 2 & 1.5 & 0.18 & 37.50 & 1.57 & 26.00 & 1.41 & 3.30 & 0.52 \\
\hline KETOCONAZOLE & Train. & 200 & 4.7 & 1 & & & & & & & 2.00 & 0.30 \\
\hline KETOPROFEN & Train. & 225 & 7.6 & 3 & 0.13 & -0.89 & 1.63 & 0.21 & 1.60 & 0.20 & 2.10 & 0.32 \\
\hline LAMOTRIGINE & Test & 25 & 4 & 1 & 1.1 & 0.04 & 2.44 & 0.39 & 0.58 & -0.24 & 25.00 & 1.40 \\
\hline LANSOPRAZOLE & Test & 15 & 7.1 & 1 & 0.28 & -0.55 & 14.00 & 1.15 & 4.40 & 0.64 & 1.00 & 0.00 \\
\hline LEFLUNOMIDE & Test & 100 & 4.9 & 1 & 0.13 & -0.89 & 13.00 & 1.11 & & & 336.00 & 2.53 \\
\hline
\end{tabular}




\begin{tabular}{|c|c|c|c|c|c|c|c|c|c|c|c|c|}
\hline LETROZOLE & Test & 3 & 7.9 & 1 & 1.9 & 0.28 & 4.63 & 0.67 & 0.57 & -0.24 & 45.00 & 1.65 \\
\hline LORAZEPAM & Train. & 3 & 8.9 & 3 & 1.3 & 0.11 & 14.44 & 1.16 & 1.00 & 0.00 & 17.00 & 1.23 \\
\hline LOVASTATIN & Test & 10 & 9.5 & 1 & 0.87 & -0.06 & 21.75 & 1.34 & 7.20 & 0.86 & 1.40 & 0.15 \\
\hline $\begin{array}{l}\text { LOXAPINE } \\
\text { SUCCINATE }\end{array}$ & Test & 40 & 8.3 & 2 & & & & & & & 4.00 & 0.60 \\
\hline $\begin{array}{l}\text { MAPROTILINE } \\
\text { HYDROCHLORIDE }\end{array}$ & Train. & 75 & 4.4 & 3 & 45 & 1.65 & 409.09 & 2.61 & 14.00 & 1.15 & 51.00 & 1.71 \\
\hline MEBENDAZOLE & Train. & 200 & 6.7 & 2 & 1.2 & 0.08 & 13.33 & 1.12 & 15.00 & 1.18 & 1.10 & 0.04 \\
\hline MERCAPTOPURINE & Test & 3 & 4.8 & 1 & 1 & 0.00 & 1.18 & 0.07 & 15.00 & 1.18 & 1.00 & 0.00 \\
\hline $\begin{array}{l}\text { METHYL- } \\
\text { PREDNISOLONE }\end{array}$ & Train. & 4 & 6.3 & 1 & 1.2 & 0.08 & 5.22 & 0.72 & 6.10 & 0.79 & 2.30 & 0.36 \\
\hline $\begin{array}{l}\text { METOCLOPRAMIDE } \\
\text { HYDROCHLORIDE }\end{array}$ & Test & 20 & 8.4 & 2 & 3.2 & 0.51 & 5.33 & 0.73 & 5.70 & 0.76 & 7.20 & 0.86 \\
\hline METOLAZONE & Test & 3 & 5.7 & 1 & & & & & & & 14.00 & 1.15 \\
\hline MIANSERIN & Train. & 60 & 8.1 & 2 & & & & & & & 13.50 & 1.13 \\
\hline $\begin{array}{l}\text { MIBEFRADIL } \\
\text { DIHYDROCHLORIDE }\end{array}$ & Test & 50 & 6.2 & 1 & 3.1 & 0.49 & 310.00 & 2.49 & 4.00 & 0.60 & 13.00 & 1.11 \\
\hline MIFEPRISTONE & Test & 600 & 8 & 1 & & & & & & & 18.00 & 1.26 \\
\hline $\begin{array}{l}\text { MYCOPHENOLIC } \\
\text { ACID }\end{array}$ & Test & 1440 & 8 & 2 & 0.77 & -0.11 & 38.50 & 1.59 & 2.00 & 0.30 & 12.00 & 1.08 \\
\hline NADOLOL & Train. & 40 & 8.9 & 1 & 1.9 & 0.28 & 13.57 & 1.13 & 2.90 & 0.46 & 9.20 & 0.96 \\
\hline NAPROXEN & Train. & 1000 & 5.2 & 2 & & & & & & & 15.00 & 1.18 \\
\hline $\begin{array}{l}\text { NEOSTIGMINE } \\
\text { BROMIDE }\end{array}$ & Train. & 15 & 7.4 & 1 & 0.74 & -0.13 & & & 9.20 & 0.96 & 1.30 & 0.11 \\
\hline NEVIRAPINE & Test & 200 & 8 & 1 & 1.3 & 0.11 & 4.06 & 0.61 & 0.30 & -0.52 & 53.00 & 1.72 \\
\hline $\begin{array}{l}\text { NICARDIPINE } \\
\text { HYDROCHLORIDE }\end{array}$ & Train. & 60 & 5.6 & 2 & 1 & 0.00 & 100.00 & 2.00 & 11.00 & 1.04 & 4.10 & 0.61 \\
\hline NIMESULIDE & Test & 400 & 4.4 & 2 & & & & & & & 2.80 & 0.45 \\
\hline NIMODIPINE & Test & 120 & 9.6 & 4 & 1.1 & 0.04 & 55.00 & 1.74 & 15.00 & 1.18 & 1.30 & 0.11 \\
\hline NISOLDIPINE & Test & 20 & 9.8 & 1 & 5.5 & 0.74 & & & 15.00 & 1.18 & 11.00 & 1.04 \\
\hline NITRENDIPINE & test & 20 & 7.6 & 2 & 6.1 & 0.79 & 305.0 & 2.48 & 25.00 & 1.40 & 8.20 & 0.91 \\
\hline $\begin{array}{l}\text { NORTRIPTYLINE } \\
\text { HYDROCHLORIDE }\end{array}$ & Train. & 75 & 9 & 3 & 22 & 1.34 & 183.33 & 2.26 & 10.00 & 1.00 & 30.00 & 1.48 \\
\hline OLANZAPINE & Test & 10 & 7.5 & 1 & 14.3 & 1.16 & 204.29 & 2.31 & 7.14 & 0.85 & 37.50 & 1.57 \\
\hline PENTOXIFYLLINE & Train. & 800 & 3.7 & 2 & 1.8 & 0.26 & 6.00 & 0.78 & 39.00 & 1.59 & 1.20 & 0.08 \\
\hline $\begin{array}{l}\text { PERGOLIDE } \\
\text { MESYLATE }\end{array}$ & Test & 0 & 8.9 & 1 & & & & & & & 27.00 & 1.43 \\
\hline PHENYTOIN & Train. & 90 & 4.2 & 1 & & & & & & & 22.00 & 1.34 \\
\hline PIMOZIDE & Test & 8 & 9.6 & 2 & & & & & & & 29.30 & 1.47 \\
\hline $\begin{array}{l}\text { PIOGLITAZONE } \\
\text { HYDROCHLORIDE }\end{array}$ & Test & 15 & 4.5 & 1 & 0.63 & -0.20 & 63.00 & 1.80 & & & 5.00 & 0.70 \\
\hline PIROXICAM & Train. & 20 & 6.7 & 1 & 0.14 & -0.85 & 2.33 & 0.37 & & & 58.00 & 1.76 \\
\hline $\begin{array}{l}\text { PRAVASTATIN } \\
\text { SODIUM }\end{array}$ & Test & 40 & 8.2 & 1 & 0.46 & -0.34 & 0.92 & -0.04 & 14.00 & 1.15 & 0.80 & -0.10 \\
\hline $\begin{array}{l}\text { PRAZOSIN } \\
\text { HYDROCHLORIDE }\end{array}$ & Train. & 2 & 8.9 & 3 & 0.73 & -0.14 & 12.17 & 1.09 & 4.70 & 0.67 & 2.00 & 0.30 \\
\hline $\begin{array}{l}\text { PRIMAQUINE } \\
\text { PHOSPHATE }\end{array}$ & Test & 15 & 5.4 & 1 & 4 & 0.60 & & & 5.80 & 0.76 & 7.10 & 0.85 \\
\hline
\end{tabular}




\begin{tabular}{|c|c|c|c|c|c|c|c|c|c|c|c|c|}
\hline PROBENECID & Train. & 1000 & 3.8 & 2 & 0.13 & -0.89 & 1.00 & 0.00 & 0.25 & -0.60 & 5.90 & 0.77 \\
\hline $\begin{array}{l}\text { PROCHLORPERAZIN } \\
\text { E MALEATE }\end{array}$ & Test & 15 & 8.5 & 3 & 22 & 1.34 & & & 16.00 & 1.20 & 9.00 & 0.95 \\
\hline $\begin{array}{l}\text { PROCYCLIDINE } \\
\text { HYDROCHLORIDE }\end{array}$ & Test & 8 & 8.6 & 3 & 0.74 & -0.13 & & & 0.86 & -0.07 & 12.00 & 1.08 \\
\hline $\begin{array}{l}\text { PROMETHAZINE } \\
\text { HYDROCHLORIDE }\end{array}$ & Test & 50 & 8.2 & 2 & 14 & 1.15 & 155.56 & 2.19 & 14.00 & 1.15 & 14.00 & 1.15 \\
\hline $\begin{array}{l}\text { PROPAFENONE } \\
\text { HYDROCHLORIDE }\end{array}$ & Test & 450 & 5.7 & 3 & 2.2 & 0.34 & 55.00 & 1.74 & 16.00 & 1.20 & 2.10 & 0.32 \\
\hline PROPRANOLOL HCL & Train. & 160 & 9.4 & 2 & 3.1 & 0.49 & 23.85 & 1.38 & 12.00 & 1.08 & 3.40 & 0.53 \\
\hline $\begin{array}{l}\text { PROTRIPTYLINE } \\
\text { HYDROCHLORIDE }\end{array}$ & Test & 15 & 5.6 & 3 & 22 & 1.34 & & & & & & \\
\hline QUININE SULFATE & Train. & 1800 & 6.3 & 6 & 1.8 & 0.26 & 6.00 & 0.78 & 1.90 & 0.28 & 11.00 & 1.04 \\
\hline RILUZOLE & Test & 100 & 4.4 & 2 & & & & & & & 12.00 & 1.08 \\
\hline ROXITHROMYCIN & Test & 450 & 6.8 & 3 & & & 0.00 & & & & 12.00 & 1.08 \\
\hline SAQUINAVIR & Test & 2000 & 8.3 & 2 & 3.6 & 0.56 & 120.00 & 2.08 & 13.00 & 1.11 & 13.00 & 1.11 \\
\hline SIMVASTATIN & Test & 40 & 8.4 & 1 & & & & & & & 3.00 & 0.48 \\
\hline SULFINPYRAZONE & Train. & 100 & 3.3 & 1 & 0.12 & -0.92 & 6.00 & 0.78 & 0.34 & -0.47 & 6.20 & 0.79 \\
\hline SUMATRIPTAN & Test & 75 & 8.1 & 3 & 1.7 & 0.23 & 2.05 & 0.31 & 19.00 & 1.28 & 1.70 & 0.23 \\
\hline $\begin{array}{l}\text { TAMSULOSIN } \\
\text { HYDROCHLORIDE }\end{array}$ & Test & 2 & 11 & 2 & 0.21 & -0.68 & 21.00 & 1.32 & 0.62 & -0.21 & 6.80 & 0.83 \\
\hline $\begin{array}{l}\text { TRAZODONE } \\
\text { HYDROCHLORIDE }\end{array}$ & Train. & 150 & 6.3 & 1 & 0.52 & -0.28 & & & 1.40 & 0.15 & 7.30 & 0.86 \\
\hline $\begin{array}{l}\text { VENLAFAXINE } \\
\text { HYDROCHLORIDE }\end{array}$ & Test & 75 & 7.7 & 2 & 4.4 & 0.64 & 6.03 & 0.78 & 14.00 & 1.15 & 5.00 & 0.70 \\
\hline $\begin{array}{l}\text { VERAPAMIL } \\
\text { HYDROCHLORIDE }\end{array}$ & Test & 120 & 6.9 & 3 & 3.7 & 0.57 & 41.11 & 1.61 & 18.00 & 1.26 & 2.80 & 0.45 \\
\hline
\end{tabular}

Table A2. Measured biomimetic properties and estimated volume of distribution, unbound volume of distribution based on the published models. \%HSA binding is obtained from the log $t_{\mathrm{R}}$ vs $\log k(\mathrm{HSA})$ calibration plot using \%HSA= $101^{*} 10^{\log k(\mathrm{HSA})} /\left(1+10^{\log k(\mathrm{HSA})}\right), \log K(\mathrm{HSA})=\exp (\log k(\mathrm{HSA}) ; \log K(\mathrm{IAM})$ obtained from measured IAM MB as described by Equation (1); IAM MB/PB DE $E_{\max }$ is calculated from $V_{\mathrm{du}}$ as $100 / V_{\mathrm{du}}$ where $\log V_{\mathrm{du}}$ is obtained as a sum of log $K$ (IAM) and $\log K(\mathrm{HSA})$ according to Equation (4); IAM MB/PB $\log V_{\text {dss }}$ is obtained from the difference between log $K$ (IAM) and $\log K(\mathrm{HSA})$ as described by Equation 3. The test/training marks are based whether it was used in the model building for $V_{\mathrm{du}}[43]$.

\begin{tabular}{|c|c|c|c|c|c|c|c|c|}
\hline DRUG & $\begin{array}{l}\text { Test or } \\
\text { training } \\
\text { set of } \\
\text { compound }\end{array}$ & $\begin{array}{c}\text { \%HSA } \\
\text { binding }\end{array}$ & $\begin{array}{c}\text { log } K(\text { HAS) } \\
\text { Converted } \\
\text { to } \log P \\
\text { scale }\end{array}$ & $\begin{array}{c}\log K \\
\text { (IAM) } \\
\text { converted } \\
\text { to } \log P \\
\text { scale }\end{array}$ & $\begin{array}{c}I A M \\
M B / P B \\
D E_{\max } \\
(\%)\end{array}$ & $\begin{array}{c}\text { IAM } \\
\text { MB/PB } \\
\log V_{d u}\end{array}$ & $\begin{array}{c}\text { IAM } \\
\text { MB/PB } \\
\log V_{\text {dss }}\end{array}$ & $\begin{array}{l}\text { Acid/base } \\
\text { character }\end{array}$ \\
\hline ABACAVIR & test & 31.9 & 0.71 & 1.77 & 60.9 & 0.21 & -0.04 & Weak Base \\
\hline $\begin{array}{l}\text { ACEBUTOLOL } \\
\text { HYDROCHLORIDE }\end{array}$ & test & 32.7 & 0.73 & 1.59 & 72.1 & 0.13 & -0.12 & Basic \\
\hline ACETYLSALICYLIC ACID & test & 66.4 & 1.33 & & & & & Acidic \\
\hline ACRIVASTINE & test & 82.5 & 1.91 & 2.68 & 13.2 & 0.87 & 0.10 & Weak Base \\
\hline
\end{tabular}




\begin{tabular}{|c|c|c|c|c|c|c|c|c|}
\hline ALBUTEROL SULFATE & test & 22 & 0.57 & 1.55 & 81.6 & 0.08 & -0.10 & Basic \\
\hline ALLOPURINOL & & 19.2 & 0.53 & 2 & 54.9 & 0.26 & 0.10 & Acidic \\
\hline $\begin{array}{l}\text { ALOSETRON } \\
\text { HYDROCHLORIDE }\end{array}$ & test & 75.5 & 1.60 & 2.68 & 15.8 & 0.80 & 0.17 & Weak Base \\
\hline $\begin{array}{l}\text { AMILORIDE } \\
\text { HYDROCHLORIDE }\end{array}$ & training & 38.6 & 0.81 & 2.56 & 27.3 & 0.57 & 0.29 & Acidic \\
\hline AMINOGLUTETHIMIDE & training & 25.9 & 0.63 & 1.53 & 81 & 0.08 & -0.13 & Weak Base \\
\hline $\begin{array}{l}\text { AMITRIPTYLINE } \\
\text { HYDROCHLORIDE }\end{array}$ & test & 90.1 & 2.50 & 6.3 & 0.308 & 2.56 & 1.56 & Basic \\
\hline AMOXAPINE & test & 88.4 & 2.33 & 6.64 & 0.24 & 2.67 & 1.75 & Basic \\
\hline ARIPIPRAZOLE & test & 97.8 & 4.42 & 6.08 & 0.129 & 2.91 & 1.04 & Basic \\
\hline $\begin{array}{l}\text { ATOMOXETINE } \\
\text { HYDROCHLORIDE1 }\end{array}$ & test & 87.5 & 2.25 & 5.28 & 0.922 & 2.07 & 1.17 & Basic \\
\hline BENDROFLUMETHIAZIDE & test & 64.4 & 1.28 & 2.95 & 12.7 & 0.84 & 0.36 & Weak Acid \\
\hline BICALUTAMIDE & test & 96.8 & 3.91 & 3.21 & 2.66 & 1.56 & -0.11 & Neutral \\
\hline $\begin{array}{l}\text { BUPROPION } \\
\text { HYDROCHLORIDE }\end{array}$ & test & 73.9 & 1.55 & 3.21 & 9.7 & 1.02 & 0.41 & Basic \\
\hline CABERGOLINE & test & 83.6 & 1.98 & 6.41 & 0.366 & 2.49 & 1.73 & Basic \\
\hline CAFFEINE & test & 26.8 & 0.64 & 1.22 & 108 & -0.05 & -0.26 & Neutral \\
\hline CANDESARTAN CILEXETIL & test & 97.9 & 4.48 & 3.8 & 1.07 & 1.94 & 0.03 & Acidic \\
\hline CARBAMAZEPINE & test & 79.9 & 1.78 & 2.34 & 19.7 & 0.70 & -0.02 & Neutral \\
\hline CELECOXIB & test & 97.1 & 4.04 & 3.9 & 1.24 & 1.89 & 0.17 & Neutral \\
\hline CILOSTAZOL & test & 89.9 & 2.48 & 3.02 & 6.97 & 1.15 & 0.12 & \\
\hline $\begin{array}{l}\text { CITALOPRAM } \\
\text { HYDROBROMIDE }\end{array}$ & test & 72.4 & 1.50 & 4.85 & 2.12 & 1.71 & 1.14 & Basic \\
\hline $\begin{array}{l}\text { CLOMIPRAMINE } \\
\text { HYDROCHLORIDE }\end{array}$ & test & 94.4 & 3.18 & 7.6 & 0.06 & 3.28 & 1.99 & Basic \\
\hline $\begin{array}{l}\text { CLONIDINE } \\
\text { HYDROCHLORIDE }\end{array}$ & test & 37.7 & 0.80 & 1.96 & 48.9 & 0.31 & 0.03 & Basic \\
\hline DAPSONE & test & 80.6 & 1.82 & 2.07 & 25 & 0.59 & -0.15 & Neutral \\
\hline DESLORATADINE & test & 88.5 & 2.34 & 6.13 & 0.39 & 2.45 & 1.52 & Basic \\
\hline DIAZOXIDE & training & 77.6 & 1.68 & 2.05 & 27.3 & 0.55 & -0.13 & Acidic \\
\hline DIDANOSINE & test & 27.5 & 0.65 & & & & & Weak Acid \\
\hline DIFLUNISAL & test & 98.8 & 5.22 & 2.49 & 2.57 & 1.55 & -0.71 & Acidic \\
\hline $\begin{array}{l}\text { DIPHENHYDRAMINE } \\
\text { HYDROCHLORIDE }\end{array}$ & test & 68.7 & 1.39 & 2.98 & 13.3 & 0.88 & 0.35 & Basic \\
\hline DIPYRIDAMOLE & test & 88.2 & 2.31 & 4.03 & 2.93 & 1.54 & 0.60 & Weak Base \\
\hline DOMPERIDONE & test & 92.2 & 2.77 & 3.96 & 2.43 & 1.62 & 0.47 & Basic \\
\hline $\begin{array}{l}\text { DONEPEZIL } \\
\text { HYDROCHLORIDE }\end{array}$ & test & 86.1 & 2.14 & 3.68 & 4.45 & 1.36 & 0.49 & Basic \\
\hline EFAVIRENZ & test & 97.3 & 4.14 & 4.34 & 0.777 & 2.10 & 0.34 & \\
\hline ETODOLAC & test & 95.6 & 3.48 & 2.51 & 6.52 & 1.16 & -0.32 & Acidic \\
\hline FELBAMATE & test & 68.7 & 1.39 & 1.76 & 42.3 & 0.36 & -0.19 & Neutral \\
\hline FELODIPINE & test & 95.9 & 3.58 & 4.45 & 0.965 & 2.02 & 0.51 & Neutral \\
\hline
\end{tabular}




\begin{tabular}{|c|c|c|c|c|c|c|c|c|}
\hline $\begin{array}{l}\text { FEXOFENADINE } \\
\text { HYDROCHLORIDE }\end{array}$ & test & 74.1 & 1.55 & 2.64 & 16.6 & 0.77 & 0.16 & Basic \\
\hline FINASTERIDE & test & 88.4 & 2.33 & 3.34 & 5.55 & 1.25 & 0.30 & \\
\hline $\begin{array}{l}\text { FLUOXETINE } \\
\text { HYDROCHLORIDE }\end{array}$ & test & 91.2 & 2.63 & 6.19 & 0.305 & 2.55 & 1.48 & Basic \\
\hline FLURBIPROFEN & test & 98.6 & 5.02 & 1.99 & 4.77 & 1.29 & -0.89 & Acidic \\
\hline FLUTAMIDE & test & 94.3 & 3.15 & 3.48 & 3.11 & 1.50 & 0.18 & Neutral \\
\hline FLUVOXAMINE MALEATE & test & 72.3 & 1.49 & 5.15 & 1.59 & 1.84 & 1.28 & Basic \\
\hline FUROSEMIDE & test & 89.7 & 2.46 & 2.14 & 12.4 & 0.77 & -0.26 & Acidic \\
\hline GLIBENCLAMIDE & test & 98 & 4.55 & 2.7 & 2.99 & 1.49 & -0.47 & Acidic \\
\hline GLIMEPIRIDE & test & 98 & 4.55 & 2.53 & 3.61 & 1.41 & -0.55 & Acidic \\
\hline GLIPIZIDE & test & 95.8 & 3.54 & 1.83 & 12 & 0.88 & -0.63 & Acidic \\
\hline $\begin{array}{l}\text { GRANISETRON } \\
\text { HYDROCHLORIDE }\end{array}$ & test & 69 & 1.40 & 4.34 & 3.57 & 1.47 & 0.94 & Basic \\
\hline GUANABENZ ACETATE & test & 88.1 & 2.30 & 4.85 & 1.36 & 1.90 & 0.97 & Basic \\
\hline HALOPERIDOL & test & 90.4 & 2.54 & 4.6 & 1.46 & 1.84 & 0.81 & Basic \\
\hline HYDROCHLOROTHIAZIDE & test & 45.4 & 0.92 & 1.62 & 63.3 & 0.19 & -0.15 & \\
\hline $\begin{array}{l}\text { IMIPRAMINE } \\
\text { HYDROCHLORIDE }\end{array}$ & test & 86.3 & 2.16 & 4.23 & 2.63 & 1.59 & 0.73 & Basic \\
\hline INDAPAMIDE & test & 75.1 & 1.59 & 2.6 & 17.1 & 0.76 & 0.13 & Weak Acid \\
\hline INDOMETACIN & test & 98.6 & 5.02 & 2.34 & 3.33 & 1.44 & -0.74 & Acidic \\
\hline IRBESARTAN & test & 96.1 & 3.64 & 2.17 & 8.18 & 1.05 & -0.51 & Acidic \\
\hline ISRADIPINE & test & 94.4 & 3.18 & 3.48 & 3.05 & 1.51 & 0.17 & Neutral \\
\hline KETOCONAZOLE & training & 94.6 & 3.22 & 3.59 & 2.69 & 1.56 & 0.21 & Weak Base \\
\hline KETOPROFEN & test & 98.4 & 4.85 & 2.18 & 4.3 & 1.33 & -0.77 & Acidic \\
\hline LAMOTRIGINE & test & 59.5 & 1.17 & 1.99 & 38.5 & 0.40 & -0.04 & Weak Base \\
\hline LANSOPRAZOLE & test & 90.5 & 2.55 & 2.66 & 9.45 & 1.01 & -0.05 & \\
\hline LEFLUNOMIDE & test & 92.6 & 2.84 & 3.37 & 4.07 & 1.38 & 0.20 & Neutral \\
\hline LETROZOLE & test & 59.3 & 1.17 & 2.42 & 25.7 & 0.59 & 0.15 & Neutral \\
\hline LORAZEPAM & test & 91.1 & 2.62 & 3.16 & 5.67 & 1.24 & 0.15 & Neutral \\
\hline LOVASTATIN & test & 95.5 & 3.45 & 4.09 & 1.47 & 1.83 & 0.38 & Neutral \\
\hline LOXAPINE SUCCINATE & test & 92.7 & 2.85 & 5.28 & 0.658 & 2.21 & 1.04 & Basic \\
\hline $\begin{array}{l}\text { MAPROTILINE } \\
\text { HYDROCHLORIDE }\end{array}$ & training & 86 & 2.13 & 6.7 & 0.25 & 2.65 & 1.82 & Basic \\
\hline MEBENDAZOLE & test & 92.9 & 2.89 & 3.07 & 5.25 & 1.26 & 0.06 & Weak Base \\
\hline MERCAPTOPURINE & test & 41.2 & 0.85 & & & & & \\
\hline METHYLPREDNISOLONE & test & 71.9 & 1.48 & 2.6 & 18.2 & 0.74 & 0.16 & Neutral \\
\hline $\begin{array}{l}\text { METOCLOPRAMIDE } \\
\text { HYDROCHLORIDE }\end{array}$ & test & 58.9 & 1.16 & 3.54 & 8.87 & 1.07 & 0.64 & Basic \\
\hline METOLAZONE & test & 83.8 & 1.99 & 2.49 & 15.2 & 0.81 & 0.00 & Neutral \\
\hline MIANSERIN & test & 91.9 & 2.73 & 5.47 & 0.595 & 2.26 & 1.15 & Basic \\
\hline $\begin{array}{l}\text { MIBEFRADIL } \\
\text { DIHYDROCHLORIDE }\end{array}$ & test & 93.6 & 3.01 & 6.3 & 0.231 & 2.68 & 1.45 & Basic \\
\hline MIFEPRISTONE & test & 95.5 & 3.45 & 4.2 & 1.33 & 1.88 & 0.43 & \\
\hline
\end{tabular}




\begin{tabular}{|c|c|c|c|c|c|c|c|c|}
\hline MYCOPHENOLIC ACID & test & 95.5 & 3.45 & 1.83 & 12.7 & 0.86 & -0.61 & Acidic \\
\hline NADOLOL & test & 39.7 & 0.83 & 1.76 & 58.5 & 0.23 & -0.07 & \\
\hline NAPROXEN & test & 99.9 & 7.09 & 1.96 & 1.55 & 1.75 & -1.36 & Acidic \\
\hline NEOSTIGMINE BROMIDE & test & 87.6 & 2.26 & 1.68 & 28.1 & 0.52 & -0.42 & Basic \\
\hline NEVIRAPINE & test & 54 & 1.06 & 1.89 & 45 & 0.34 & -0.06 & Neutral \\
\hline $\begin{array}{l}\text { NICARDIPINE } \\
\text { HYDROCHLORIDE }\end{array}$ & test & 95.8 & 3.54 & 4.23 & 1.21 & 1.91 & 0.42 & Weak Base \\
\hline NIMESULIDE & test & 98 & 4.55 & 2.32 & 4.4 & 1.32 & -0.64 & Acidic \\
\hline NIMODIPINE & test & 92 & 2.74 & 3.09 & 5.64 & 1.24 & 0.10 & Neutral \\
\hline NISOLDIPINE & test & 91 & 2.61 & 3.16 & 5.67 & 1.24 & 0.16 & Neutral \\
\hline NITRENDIPINE & test & 93.9 & 3.07 & 3.59 & 2.88 & 1.53 & 0.24 & Neutral \\
\hline $\begin{array}{l}\text { NORTRIPTYLINE } \\
\text { HYDROCHLORIDE }\end{array}$ & training & 86.2 & 2.15 & 5.66 & 0.673 & 2.21 & 1.36 & Basic \\
\hline OLANZAPINE & test & 86.2 & 2.15 & 5.06 & 1.2 & 1.95 & 1.09 & Basic \\
\hline PENTOXIFYLLINE & test & 25.9 & 0.63 & 1.47 & 85.5 & 0.06 & -0.15 & Neutral \\
\hline PERGOLIDE MESYLATE & test & 85.2 & 2.08 & 5.71 & 0.672 & 2.21 & 1.40 & Basic \\
\hline PHENYTOIN & test & 83.4 & 1.97 & 2.51 & 15.1 & 0.81 & 0.01 & Weak Acid \\
\hline PIMOZIDE & test & 98.6 & 5.02 & 5.61 & 0.142 & 2.85 & 0.70 & Basic \\
\hline $\begin{array}{l}\text { PIOGLITAZONE } \\
\text { HYDROCHLORIDE }\end{array}$ & test & 97.9 & 4.48 & 2.76 & 2.97 & 1.50 & -0.43 & \\
\hline PIROXICAM & test & 97.3 & 4.14 & 1.9 & 8.14 & 1.05 & -0.73 & Acidic \\
\hline PRAVASTATIN SODIUM & test & 40.3 & 0.84 & 1.83 & 54 & 0.26 & -0.04 & Acidic \\
\hline $\begin{array}{l}\text { PRAZOSIN } \\
\text { HYDROCHLORIDE }\end{array}$ & test & 85.2 & 2.08 & 2.47 & 14.6 & 0.82 & -0.03 & Weak Base \\
\hline PRIMAQUINE PHOSPHATE & test & 79.2 & 1.75 & 4.6 & 2.31 & 1.66 & 0.98 & Basic \\
\hline PROBENECID & training & 95.4 & 3.43 & 1.81 & 13.2 & 0.85 & -0.62 & Acidic \\
\hline $\begin{array}{l}\text { PROCHLORPERAZINE } \\
\text { MALEATE }\end{array}$ & test & 96.9 & 3.95 & 7.67 & 0.037 & 3.49 & 1.85 & Basic \\
\hline $\begin{array}{l}\text { PROCYCLIDINE } \\
\text { HYDROCHLORIDE }\end{array}$ & test & 86.1 & 2.14 & 4.49 & 1.72 & 1.70 & 0.84 & Neutral \\
\hline $\begin{array}{l}\text { PROMETHAZINE } \\
\text { HYDROCHLORIDE }\end{array}$ & test & 92.5 & 2.82 & 7.2 & 0.107 & 3.02 & 1.89 & Basic \\
\hline $\begin{array}{l}\text { PROPAFENONE } \\
\text { HYDROCHLORIDE }\end{array}$ & training & 88 & 2.29 & 4.38 & 2.1 & 1.69 & 0.76 & Basic \\
\hline PROPRANOLOL HCL & test & 72.7 & 1.51 & 4.45 & 3.04 & 1.54 & 0.97 & Basic \\
\hline $\begin{array}{l}\text { PROTRIPTYLINE } \\
\text { HYDROCHLORIDE }\end{array}$ & test & 83.8 & 1.99 & 5.42 & 0.929 & 2.07 & 1.29 & Basic \\
\hline QUININE SULFATE & test & 78.1 & 1.70 & 5.19 & 1.35 & 1.90 & 1.25 & Basic \\
\hline RILUZOLE & test & 94.2 & 3.13 & 3.29 & 3.71 & 1.41 & 0.10 & Weak Base \\
\hline ROXITHROMYCIN & test & 46.6 & 0.93 & 5.37 & 1.88 & 1.80 & 1.50 & \\
\hline SAQUINAVIR & test & 95.2 & 3.37 & 3.77 & 2.07 & 1.68 & 0.26 & Weak Base \\
\hline SIMVASTATIN & test & 96.6 & 3.82 & 4.49 & 0.823 & 2.09 & 0.47 & \\
\hline SULFINPYRAZONE & training & 97.2 & 4.09 & 2.11 & 6.83 & 1.13 & -0.63 & Acidic \\
\hline SUMATRIPTAN & test & 28 & 0.66 & 2.68 & 26.5 & 0.58 & 0.37 & Basic \\
\hline
\end{tabular}




\begin{tabular}{|c|c|c|c|c|c|c|c|c|}
\hline $\begin{array}{l}\text { TAMSULOSIN } \\
\text { HYDROCHLORIDE }\end{array}$ & test & 68.9 & 1.39 & 2.84 & 14.8 & 0.82 & 0.28 & Basic \\
\hline $\begin{array}{l}\text { TRAZODONE } \\
\text { HYDROCHLORIDE }\end{array}$ & test & 92 & 2.74 & 3.04 & 5.81 & 1.22 & 0.07 & Weak Base \\
\hline $\begin{array}{l}\text { VENLAFAXINE } \\
\text { HYDROCHLORIDE }\end{array}$ & test & 35 & 0.76 & 3.19 & 15.5 & 0.83 & 0.58 & Basic \\
\hline $\begin{array}{l}\text { VERAPAMIL } \\
\text { HYDROCHLORIDE }\end{array}$ & test & 88.1 & 2.30 & 3.59 & 3.93 & 1.35 & 0.41 & Basic \\
\hline ZAFIRLUKAST & test & 99.1 & 5.57 & 3.67 & 0.789 & 2.14 & -0.27 & Acidic \\
\hline ZALCITABINE & test & 23.6 & 0.60 & & & & & Zwitterionic \\
\hline ZIDOVUDINE & test & 11.9 & 0.42 & 1.17 & 127 & -0.12 & -0.24 & Weak Acid \\
\hline ZILEUTON & training & 89.7 & 2.46 & 2.53 & 10.46 & 0.93 & -0.09 & Neutral \\
\hline $\begin{array}{l}\text { ZIPRASIDONE } \\
\text { HYDROCHLORIDE }\end{array}$ & training & 97.2 & 4.09 & 4.64 & 0.596 & 2.22 & 0.48 & Weak Base \\
\hline ZOLMITRIPTAN & training & 61.4 & 1.21 & 2.78 & 16.3 & 0.75 & 0.30 & Basic \\
\hline
\end{tabular}

(C2017 by the authors; licensee IAPC, Zagreb, Croatia. This article is an open-access article distributed under the terms and conditions of the Creative Commons Attribution license (http://creativecommons.org/licenses/by/3.0/) (cc) B EY 